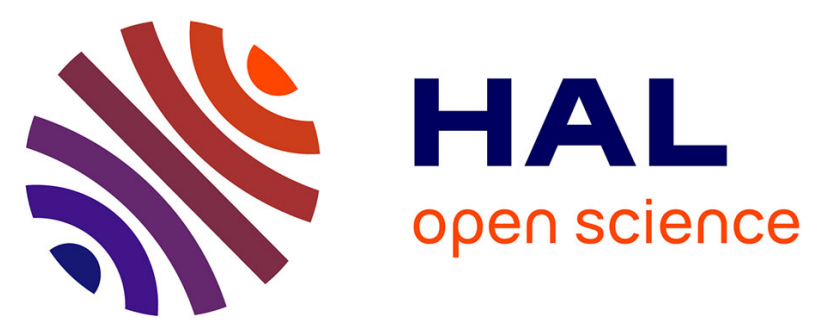

\title{
Natural gas extraction and artificial gas injection experiments in Opalinus Clay, Mont Terri rock laboratory (Switzerland)
}

Agnès Vinsot, C. Anthony J. Appelo, Mélanie Lundy, Stefan Wechner, Cristelle Cailteau-Fischbach, Philippe de Donato, Jacques Pironon, Yanick Lettry, Catherine Lerouge, Pierre de Cannière

\section{To cite this version:}

Agnès Vinsot, C. Anthony J. Appelo, Mélanie Lundy, Stefan Wechner, Cristelle Cailteau-Fischbach, et al.. Natural gas extraction and artificial gas injection experiments in Opalinus Clay, Mont Terri rock laboratory (Switzerland). Swiss Journal of Geosciences, 2017, 110 (1), pp.375-390. 10.1007/s00015016-0244-1 . insu-01476435

\section{HAL Id: insu-01476435 \\ https://hal-insu.archives-ouvertes.fr/insu-01476435}

Submitted on 6 May 2017

HAL is a multi-disciplinary open access archive for the deposit and dissemination of scientific research documents, whether they are published or not. The documents may come from teaching and research institutions in France or abroad, or from public or private research centers.
L'archive ouverte pluridisciplinaire HAL, est destinée au dépôt et à la diffusion de documents scientifiques de niveau recherche, publiés ou non, émanant des établissements d'enseignement et de recherche français ou étrangers, des laboratoires publics ou privés. 


\title{
Natural gas extraction and artificial gas injection experiments in Opalinus Clay, Mont Terri rock laboratory (Switzerland)
}

\author{
Agnès Vinsot $^{1}$ - C. Anthony J. Appelo ${ }^{2} \cdot$ Mélanie Lundy $^{1} \cdot$ Stefan Wechner $^{3}$ • \\ Cristelle Cailteau-Fischbach ${ }^{1,4,5} \cdot$ Philippe de Donato $^{4} \cdot$ Jacques Pironon $^{4}$. \\ Yanick Lettry $^{6} \cdot$ Catherine Lerouge $^{7} \cdot$ Pierre De Cannière $^{8}$
}

Received: 28 April 2016/ Accepted: 9 December 2016/Published online: 23 February 2017

(C) The Author(s) 2017. This article is published with open access at Springerlink.com

\begin{abstract}
Two experiments have been installed at Mont Terri in 2004 and 2009 that allowed gas circulation within a borehole at a pressure between 1 and 2 bar. These experiments made it possible to observe the natural gases that were initially dissolved in pore-water degassing into the borehole and to monitor their content evolution in the borehole over several years. They also allowed for inert $(\mathrm{He}, \mathrm{Ne})$ and reactive $\left(\mathrm{H}_{2}\right)$ gases to be injected into the borehole with the aim either to determine their diffusion properties into the rock pore-water or to evaluate their removal reaction kinetics. The natural gases identified were $\mathrm{CO}_{2}$, light alkanes, $\mathrm{He}$, and more importantly $\mathrm{N}_{2}$. The natural concentration of four gases in Opalinus Clay porewater was evaluated at the experiment location: $\mathrm{N}_{2}$ $2.2 \mathrm{mmol} / \mathrm{L} \pm 25 \%, \quad \mathrm{CH}_{4} \quad 0.30 \mathrm{mmol} / \mathrm{L} \pm 25 \%, \quad \mathrm{C}_{2} \mathrm{H}_{6}$ $0.023 \mathrm{mmol} / \mathrm{L} \pm 25 \%, \quad \mathrm{C}_{3} \mathrm{H}_{8} \quad 0.012 \mathrm{mmol} / \mathrm{L} \pm 25 \%$.
\end{abstract}

Editorial handling: P. Bossart and A. G. Milnes.

This is paper \#19 of the Mont Terri Special Issue of the Swiss Journal of Geosciences (see Bossart et al. 2017, Table 3 and Fig. 7).

Electronic supplementary material The online version of this article (doi:10.1007/s00015-016-0244-1) contains supplementary material, which is available to authorized users.

Agnès Vinsot

agnes.vinsot@andra.fr

1 Agence Nationale pour la Gestion des Déchets Radioactifs ANDRA, Meuse Haute-Marne Center, RD 960, 55290 Bure, France

2 Valeriusstraat 11, $1071 \mathrm{MB}$ Amsterdam, The Netherlands

3 Hydroisotop GmbH, Woelkestraße 9, 85301 Schweitenkirchen, Germany

4 Université de Lorraine-CNRS-CREGU, GeoRessources Lab, 54506 Vandœuvre-lès-Nancy, France
Retention properties of methane, ethane, and propane were estimated. Ne injection tests helped to characterize rock diffusion properties regarding the dissolved inert gases. These experimental results are highly relevant towards evaluating how the fluid composition could possibly evolve in the drifts of a radioactive waste disposal facility.

Keywords Nitrogen · Alkane · Hydrogen · Noble gases · Diffusion $\cdot$ Nuclear waste disposal

\section{Introduction}

Opalinus Clay pore-water contains dissolved natural gases: $\mathrm{N}_{2}, \mathrm{CO}_{2}, \mathrm{CH}_{4}$ and other light alkanes, $\mathrm{He}$ and other noble gases. With the exception of $\mathrm{N}_{2}$, these gases were identified before 2000 in the Mont Terri rock laboratory thanks to measurements on gas samples extracted from cored rock samples or from boreholes (Pearson et al. 2003). Furthermore, in the framework of studies devoted to nuclear waste geological disposal feasibility, intense efforts were made on precise quantification of $\mathrm{CO}_{2}$ and $\mathrm{He}$ content in the pristine pore-water. $\mathrm{CO}_{2}$ is of key interest regarding the

5 Present Address: UPMC Univ. Paris 06, Université Versailles St-Quentin, CNRS/INSU, LATMOS-IPSL, 75252 Paris Cedex 05, France

6 Solexperts AG, Mettlenbachstrasse 25, 8617 Mönchaltorf, Switzerland

7 French Geological Survey BRGM, 3 Avenue Claude Guillemin, 45060 Orléans Cedex 2, France

8 Agence fédérale de contrôle nucléaire AFCN, Rue Ravenstein 36, 1000 Brussels, Belgium 
understanding of the processes that control the pore-water composition (Gaucher et al. 2009; Pearson et al. 2011; Tournassat et al. 2015) and He data enables to characterize transport properties of solutes within Opalinus Clay rock (Rübel et al. 2002; Mazurek et al. 2011). More generally, dissolved gases are affected by both reaction and migration processes. As a consequence, data regarding dissolved gas concentration distribution in Opalinus Clay may give some insight on both transport properties of solutes in this argillaceous rock and processes that control the pore-water composition. Regarding light alkanes, data interpretation also meets broader research topics on the relationships between their chemical and isotopic composition and the questions about their origin along with the kinetics associated to their production, their potential migration paths, their potential retention properties on clay minerals etc. (Prinzhofer and Pernaton 1997; Zhang and Krooss 2001; Sherwood Lollar et al. 2008; Prinzhofer et al. 2009; McCollom et al. 2010; Stolper et al. 2015).

In 2004, a new experimental method has been implemented at Mont Terri rock laboratory with the objective to quantify more precisely the $\mathrm{CO}_{2}$ content at the measurement location. The method is based on gas circulation, at a pressure between 1 and $2 \mathrm{bar}$, in the packed off interval of a 15-m long ascending borehole (Vinsot et al. 2008). This experiment, named pore-water chemistry (PC-C) gave a series of data on natural Opalinus Clay gases. The same method has been used since 2009 to study transport and reactivity of dissolved hydrogen gas in Opalinus Clay pore- water. This last experiment, named Hydrogen Transfer (HT), has given data on natural gases over a period of 6.5 years. In 2011, He and $\mathrm{Ne}$ were injected together with $\mathrm{H}_{2}$ in the test interval to study their transport properties in Opalinus Clay pore-water and possible $\mathrm{H}_{2}$ consumption (Vinsot et al. 2014).

This paper presents the new data regarding natural dissolved gases in Opalinus Clay pore-water obtained in these experiments and the link that may be drawn with available data obtained on core samples.

\section{Geological context and rock characteristics}

The Mont Terri rock laboratory is located in the security gallery of a motorway tunnel in the Jura Mountains (Fig. 1), in north-western Switzerland at a depth of about $300 \mathrm{~m}$ below ground level (Bossart et al. 2017). It is a "methodological laboratory" (Delay et al. 2014) in the Opalinus Clay, which is a well consolidated Jurassic age claystone with a hydraulic conductivity below $3 \times 10^{-12} \mathrm{~m} / \mathrm{s}$ (Thury and Bossart 1999).

The clay-rocks at the test locations (shaly facies) consist of a dominant clay fraction ( $\sim 60 \mathrm{wt} . \%)$ including illite, kaolinite, chlorite, and illite-smectite mixed layers, associated with quartz $(\sim 15 \mathrm{wt} . \%)$, calcite $(\sim 20 \mathrm{wt} . \%)$, feldspar, dolomite, siderite (a few wt. $\%$ each), pyrite ( $\sim 1 \mathrm{wt} . \%)$, and organic matter (around $1 \mathrm{wt} . \%$ organic C) (Pearson et al. 2003). From thin section microscope observations, the rock displays a fine grain fabric with heterogeneities. The clay
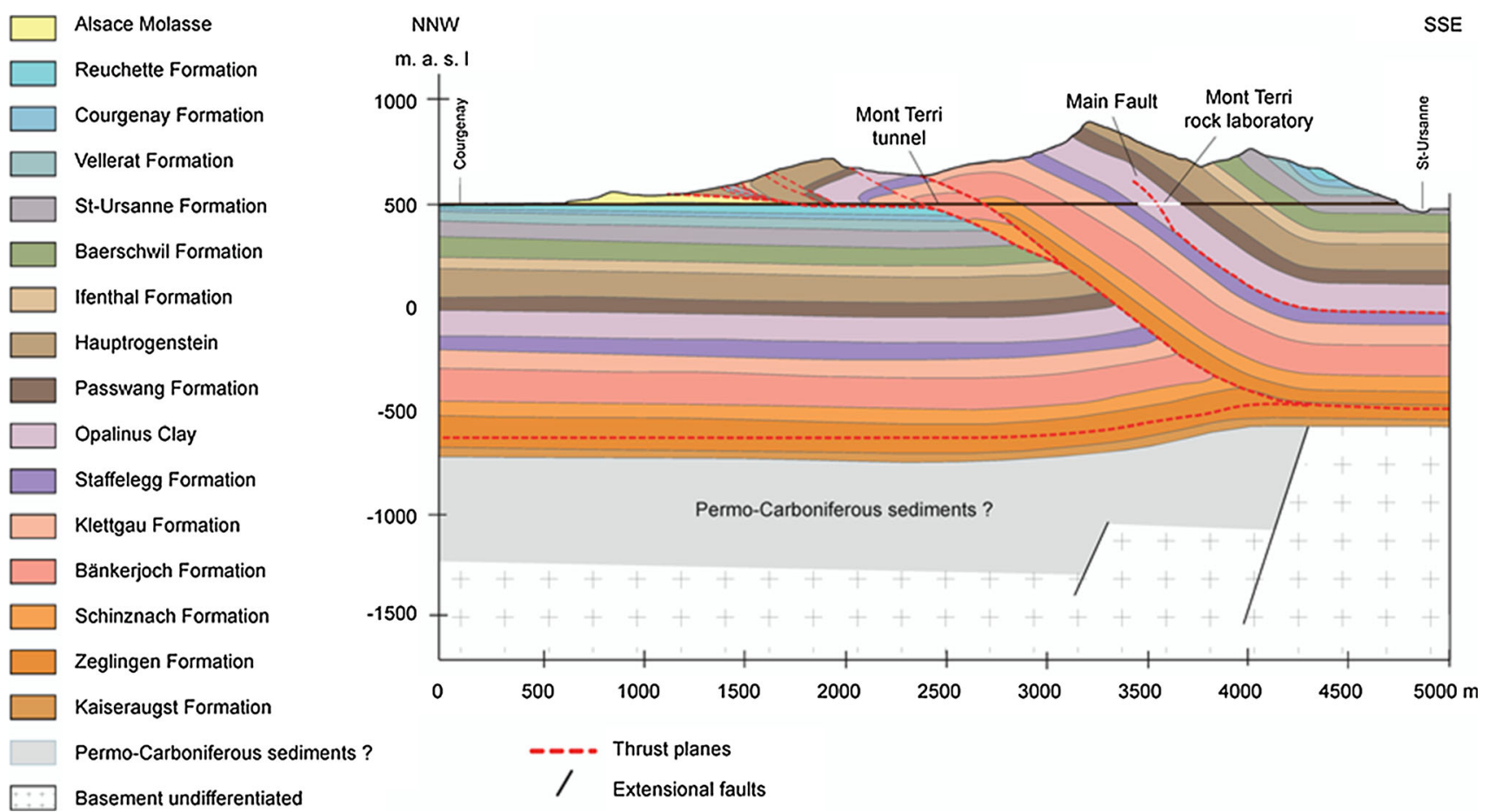

Fig. 1 Geological cross-section of the Mont Terri anticline and location of the Mont Terri rock laboratory (Nussbaum et al. 2017) 
matrix is essentially formed of detrital particles of less than $1 \mu \mathrm{m}$ of illite and illite-smectite mixed layers, with minor $10-50 \mu \mathrm{m}$ sized flakes of biotite, muscovite, and chlorite. The carbonate fraction consists of calcite test and shell fragments and diagenetic carbonates including calcite (major micrite, sparite, and rare euhedral grains), dolomite/ ankerite (essentially euhedral grains) and siderite (disseminated $\mu \mathrm{m}$-sized grains, rare clusters). Pyrite occurs as $\mu \mathrm{m}$ sized framboids of diagenetic origin. The heterogeneities of the clay-rocks are essentially due to the occurrence of the fossil debris ranging in size from $50 \mu \mathrm{m}$ to few millimetres. The fossil debris include calcite test and shell fragments, but also particles of organic matter and phosphate elements. The water content is around $7 \mathrm{wt} \%$ (with respect to the dry rock mass) and the total porosity is between 16 and $18 \%$ by volume.

\section{Experiments: setup and methods}

\subsection{Experimental layout}

Two $15 \mathrm{~m}$-long, 101 and $76 \mathrm{~mm}$ in diameters respectively, inclined ascending boreholes perpendicular to the bedding were drilled from the vault of underground drifts in the Mont Terri rock laboratory: BPC-C1 in 2004 in the PP niche from the Security Gallery and BHT-1 in 2009 in Gallery-08. Both boreholes are $20 \mathrm{~m}$ far from one another perpendicularly to the Opalinus Clay contact with the limestones of the Passwang Formation. The last $5 \mathrm{~m}$ of these boreholes constitute the test intervals in contact with the rock. These zones were drilled using nitrogen in BPC$\mathrm{C} 1$ and argon in BHT-1. The drilling tools were disinfected with chlorinated water and alcohol to minimize the introduction of external micro-organisms in the boreholes.

Immediately after coring, a device comprising an inflatable packer was installed in order to isolate the test intervals from the drift atmosphere. As soon as the packers were set in place, the test intervals were filled with argon in both boreholes. In the test intervals, the equipment took up over $80 \%$ of the volume, leaving only a maximum volume of about 5 and 10 litres remaining for fluids in BPC-C1 and BHT-1 respectively. It includes a PFA (per-fluoro-alkoxy)coated, stainless steel inner tube. BHT-1 equipment comprises ceramic filter screen pieces having a porosity of $42 \%$ and a thickness of $14.75 \mathrm{~mm}$, which surround the $40 \mathrm{~mm}$ diameter central tubing. However, BPC-C1 equipment does not include a filter screen. The intervals are closed at the

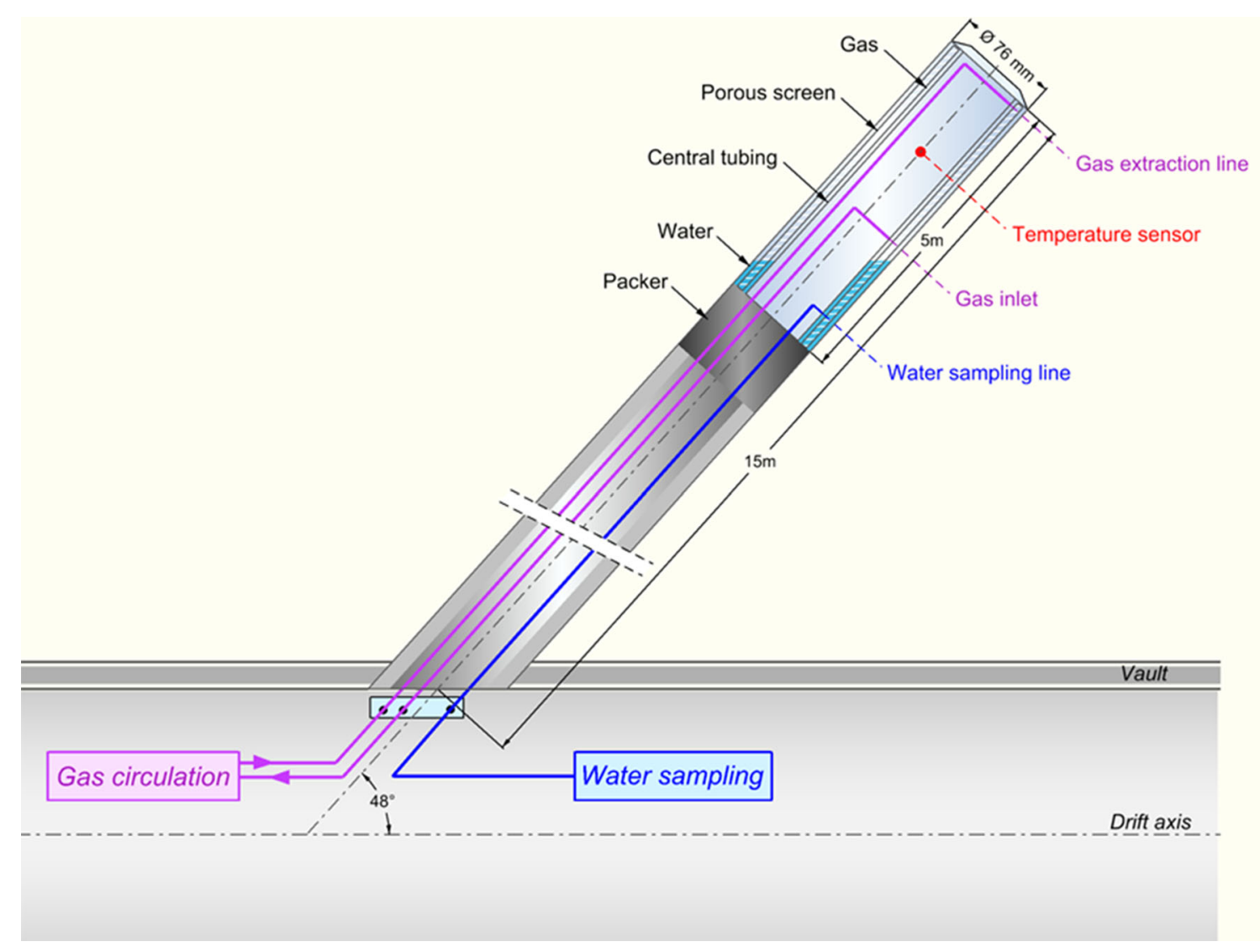

Fig. 2 Experimental layout (BHT-1) 
bottom by a packer made of either neoprene-covered natural rubber or polyurethane rubber and inflated with water. In the boreholes, 4 to 6 measurement and circulation lines made of either PEEK (poly-ether-ether-ketone) or stainless steel, pass through the central tubing and connect the test interval with the drift (Fig. 2). Two stainless steel lines are dedicated to gas circulation between the interval and the drift. The gas extraction line enters the filter a few centimetres from the top of the interval, and the gas injection line 40 to $60 \mathrm{~cm}$ from the base of the interval. At the top level in BHT-1 borehole, another stainless steel line is dedicated to pressure measurements. Two PEEK lines enter the filter $2 \mathrm{~cm}$ from the bottom of the interval; one is for water extraction, the other for pressure measurements. The pressure sensors (Keller LEO 3 pressure gauges) are located in the drift at the far end of the pressure measurement lines.

In the drift, a module comprising a KNF gas-tight pump is used for circulating the gas. This module comprises 10 Swagelok stainless steel sampling cylinders in which the gas circulates continuously. These cylinders (75 or $150 \mathrm{~mL}$ ) may be disconnected to perform gas sample analyses, without modifying the total gas pressure. Various devices were connected to the gas circuit over several time periods to perform non-destructive in-line analyses of certain gases with an infrared (Cailteau et al. 2011a, b) or a Raman spectrometer (Lundy and Vinsot 2010). In addition, the BHT-1 gas circulation module includes a HY-OPTIMA 740 by $\mathrm{H} 2$ scan $\mathrm{H}_{2}$ specific solid detector probe and a Teledyne ISCO D-500 gas injection pump.

In the rock surrounding the test intervals, the water pressure is 15 to 25 bar. In spite of the low hydraulic conductivity value of the rock (below $3 \times 10^{-12} \mathrm{~m} / \mathrm{s}$ ), the difference in pressure between the interval and the rock induces a 3 to $20 \mathrm{~mL} /$ day water seepage flow rate from the rock to the interval (Vinsot et al. 2008, 2014). The water seeping into the interval accumulates at the bottom due to gravity. In the drift, a module is used for water extraction. This module includes in-line water sampling cylinders made of either PTFE (poly-tetra-fluoro-ethylene)-coated stainless steel or PEEK. The water lines and the fittings are made of PEEK. The extraction flow rate was adjusted so that the vertical water height in the interval did not exceed $30 \mathrm{~cm}$. In the 4 or more meters above this surface, the available volume was taken up by gas, circulating between the borehole and the drift in a closed loop at a rate of $20 \mathrm{~mL} / \mathrm{min}$. This flow induced practically no head loss, thus the pressure was the same at any point of the circuit by \pm 5 mbar.

All of the sensors (pressure, gas flow rate, hydrogen, scale etc.) are connected to a central database which acquires and stores the values measured every 5 to $20 \mathrm{~min}$ (Tabani et al. 2010).

\subsection{Tests chronology}

At the beginning of each test, after having filled the test interval and the gas circulation module with pure argon at a pressure of $1.3 \pm 0.1 \mathrm{bar}$, the circulation of this gas and the monitoring of its composition were initiated.

In BPC-C1, the composition of the circulating gas was monitored over almost the entire first year of testing. During this phase, the test interval was purged twice with argon after 44 and 231 days. The most consistent set of data was obtained over 70 days after the second purge, when a uniform gas pressure along the whole gas circuit was obtained (Vinsot et al. 2008). The continuous extraction of seepage water from the test interval had started just before the second purge and the chemical composition of seepage water has been analysed in two water samples before the end of the first year (Vinsot et al. 2008). At the end of the first year, gas circulation and water extraction were stopped. As a result, the water seeping out of the rock filled the test interval. As the gases could not escape during the filling, the gas pressure increased up to a value comprised between 5 and 6 bar. Over the span of approximately a year, water had completely filled the test interval, with the exception of its top far end that contained a gas bubble. At the end of this time period, water extraction resumed. Since then, the dissolved gas concentrations have been analysed in the water samples taken in-line without any contact with the ambient air. The remaining gas bubble was eliminated 2.6 years later by extracting water from the line previously used to extract gas from the top interval.

In BHT-1, the composition of the circulating gas has been monitored continuously since the beginning, except for a period lasting half a year after the first 1.5 year of testing. Since the end of the first year, seepage water has been continuously extracted from the borehole and its composition has been regularly analysed (Vinsot et al. 2014). The dissolved gas concentrations have not been measured in the water samples. After 2 years of testing, the gas from the test interval was replaced by a mixture of gases containing $5 \mathrm{vol} \% \mathrm{H}_{2}, 5 \mathrm{vol} \% \mathrm{He}, 5 \mathrm{vol} \% \mathrm{Ne}$, and $85 \mathrm{vol} \% \mathrm{Ar}$ at a total pressure close to $1.5 \mathrm{bar}$. The objective was to study the hydrogen transport and potential hydrogen consumption processes in Opalinus Clay (Vinsot et al. 2014). The non-reactive gases $\mathrm{He}$ and $\mathrm{Ne}$ served as references as changes in their content should only depend on dissolution and diffusion processes in the rock porewater. As a consequence, they can help to calibrate the transport part in a reactive transport model. The gas pressure value was set as low as possible, in order to maximize the water flow towards the borehole, but not below the atmospheric pressure, in order to prevent air intrusion in the gas circuit. 


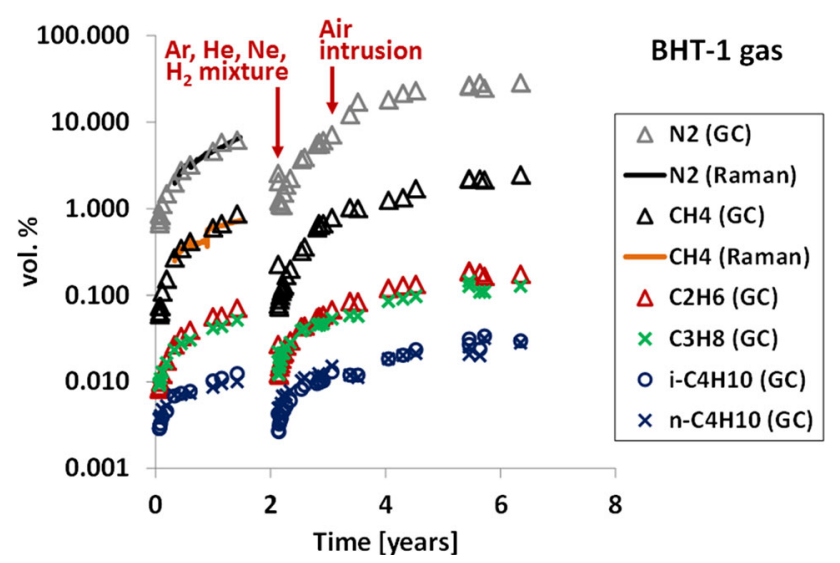

Fig. $3 \mathrm{~N}_{2}, \mathrm{CH}_{4}, \mathrm{C}_{2} \mathrm{H}_{6}, \mathrm{C}_{3} \mathrm{H}_{8}, \mathrm{i}-\mathrm{C}_{4} \mathrm{H}_{10}$, and $\mathrm{n}-\mathrm{C}_{4} \mathrm{H}_{10}$ content measured in the gas circulating in BHT-1 borehole; logarithm scale; $G C$ gas chromatography; analytical uncertainty is included within the symbol size

Half a year later, a semi-continuous hydrogen injection phase was launched. It consisted in regularly injecting pure hydrogen in order to maintain a partial pressure close to 0.06 bar in the test interval. This phase lasted 1.5 year.

In spite of the preventive maintenance, the BHT-1 experiment encountered two leakage events over the 6.5 years of its duration. The first one occurred after 1.5 year of testing. Damage to the gas circulation pump led to air being admitted into the test interval over a period of $26 \mathrm{~h}$. Then, the test interval was filled with pure argon again and closed off 9 days later for a period of 0.6 year. The second leakage event took place after approximately 3.4 years and induced an introduction of atmospheric air into the gas circuit detectable in the $\mathrm{N}_{2}$ content (Fig. 3). Air could be introduced into the gas circuit in spite of its overpressure with respect to the surrounding air because the circuit was locally depressed between the gas flow controller and the pump and a leak occurred at this location.

\subsection{Chemical analyses}

In the laboratory, the gas composition was analysed using a Shimadzu GC17A gas chromatograph equipped with two capillary columns: (a) Plot Fused Silica, Molsieve 5A, $50 \mathrm{~m} \times 0.53 \mathrm{~mm}, \mathrm{df}=50 \mu \mathrm{m}$ (Varian); (b) Plot Fused Silica, CP Poraplot Q-HT, $25 \mathrm{~m} \times 0.53 \mathrm{~mm}$, $\mathrm{df}=10 \mu \mathrm{m}$ (Varian) and two detectors: Detector 1: micro-TCD (Micro-Volume Thermal Conductivity Detector, VICI Instruments Inc.); Detector 2: FID (Flame Ionization Detector, Shimadzu). Sample attachment is carried out with a special quick connection (Swagelok), allowing direct connection of the sample cells with the evacuated inlet system of the gas chromatograph (8 Port Dual External Sample Injector, Valco Europe) without contact with the external atmospheric gases. The uncertainty affecting the gas content result is $\pm 5 \%$.

Carbon-13 content of the alkanes is analysed by a GCIRMS (IRMS Finnigan Delta S, GC 3400 Varian, resolution (5\% valley) 110 , abundance sensitivity $2 \times 10^{-5}$ for 44/45, high voltage stability: $2.1 \times 10^{-5}$ ). The alkanes are completely oxidized to $\mathrm{CO}_{2}$ in a combustion interface and then measured in the isotope ratio mass spectrometer. Measured results are corrected to carbon standards NBS18-Calcite, IAEA CO-1, NBS23-SrCO $3, \mathrm{CO}_{2}-\mathrm{lab}$ standard 1 , and $\mathrm{CO}_{2}-\mathrm{lab}$ standard 2.

The water sample cylinders were connected to a special cell to measure the $\mathrm{pH}$ without contact with the ambient air. A few $\mathrm{mL}$ of the water are immediately used for alkalinity measurement by titration. Another $2 \mathrm{~mL}$ are immediately transferred into one arm of a two-armed glass vessel, the second arm containing $\mathrm{H}_{3} \mathrm{PO}_{4}(85 \%)$. The vessel is then flushed with pure $\mathrm{N}_{2}$ and closed. Inclining the vessel causes the $\mathrm{H}_{3} \mathrm{PO}_{4}$ to mix with the sample and, as a result, the $\mathrm{CO}_{2}$ from all dissolved inorganic carbon compounds is released into the gas phase. Then, the gas phase is transferred to the evacuated sample loop of the isotope ratio mass spectrometer with dual inlet system for measurement (IRMS: MAT-250, resolution (5\% valley): 200, abundance sensitivity: $1.3 \times 10^{-6}$ for $44 / 45$; high voltage stability: $1 \times 10^{-5}$ ). Measured results are corrected to carbon standards NBS18-Calcite, NBS19-Calcite, NBS23- $\mathrm{SrCO}_{3}, \quad \mathrm{IMEP} 8-\mathrm{CO}_{2}, \mathrm{CO}_{2}-\mathrm{lab}$ standard and Hydroisotop lab standard (DIC). The 1 sigma error for clean standard material is $\pm 0.2 \%$. The $\delta^{13} \mathrm{C}$ results are related to VPDB Vienna standard (Vienna Pee Dee Belemnite) in the delta-notation.

\subsection{Volume of the gas circuits}

The values of total pressure, total volume and temperature of the circulating gas are required in order to quantify the fluxes of gas that are exchanged with the rock pore-water. In both BHT-1 and BPC-C1, the total gas pressure was continuously measured; its uncertainty value was $\pm 0.1 \%$ and its maximum variation along the gas circuits was $0.3 \%$. The theoretical volumes available for fluids in the test intervals have a value of $4.7 \mathrm{~L}$ in BPC-C1 and $9.3 \mathrm{~L}$ in BHT-1. This is based on the characteristics of the borehole equipment, assuming perfectly cylindrical boreholes. In reality, the boreholes may be deformed and, as a result, their volumes may be reduced. Moreover, the volume between the equipment and the borehole top is not precisely known. In BHT-1, two types of operations provided opportunities to estimate the actual volumes available for fluids in the test intervals at a given date by using the ideal gas law: (1) addition of empty parts (gas module or gas sampling cylinders) of known volume on the gas circuit 
inducing gas expansion; (2) extraction of known volumes of water inducing gas expansion. Such operations led to an estimation of the volume of the BHT-1 test interval of $9.5 \mathrm{~L} \pm 3 \%$. This volume is close to the theoretical one. In the case of BPC-C1, the volume available for the gases in the test interval was supposed to be the theoretical one.

During the course of the experiments, each time a gas sampling cylinder was disconnected, both the total volume available for the gases and the total mass of circulating gas decreased, whereas neither the pressure nor the gas content were modified. On the other hand, the cylinders that were added onto the gas circuit were filled with pure argon at a pressure around 20 mbar. As a result, each time a gas sampling cylinder was added, the gas pressure decreased and the total volume available for the gases increased, whereas the total mass of circulating gas and the content of each gas were nearly not affected. Furthermore, the gas volume varied inversely with the water level in the borehole interval, which depended on both the seepage and the water extraction flow rates. The water level is deduced from two absolute pressure measurements and its uncertainty value is $\pm 2 \mathrm{~cm}$. In BHT-1, the water extraction flow rate was controlled by a pressure controller and measured by a weight scale. The seepage flow rate has been estimated at a value of $12 \mathrm{~mL} /$ day. In the case of BPC-C1, the water extraction flow rate was controlled by a syringe-pump and the seepage flow rate was evaluated at around $3 \mathrm{~mL} /$ day during the first year. Unfortunately, the exact volume of the BPC-C1 gas circuit was not precisely known because a tank was inline on the gas circuit, and its volume, which had been modified for the purge operations, could not be precisely controlled. Consequently the tank volume, which maximum value was $5.4 \mathrm{~L}$, was considered as a variable parameter in the calculations.

\section{Experimental results}

\subsection{Natural gas content}

The composition monitoring of the gas circulating in boreholes BPC-C1 and BHT-1 showed the inflow of $\mathrm{N}_{2}$, light alkanes up to $\mathrm{C} 6$ and $\mathrm{CO}_{2}$. Helium was also detected, whereas oxygen was not. $\mathrm{N}_{2}$ and alkane contents increased continuously over the experiment time duration (Figs. 3, 4; Electronic Appendix-Table 1, Electronic Appendix-Table 2). $\mathrm{N}_{2}$ apart, the occurrence of these gases in the Opalinus Clay pore-water has been described by Pearson et al. (2003).

In the case of BPC-C1, an uncertainty subsisted regarding the origin of $\mathrm{N}_{2}$ because the test interval of this borehole had been cored with $\mathrm{N}_{2}$ (Vinsot et al. 2008). In the case of borehole BHT-1, for which argon was used when coring, the increase of $\mathrm{N}_{2}$ content in the circulating gas over time showed that this gas arises from pore-water.
BPC-C1 gas

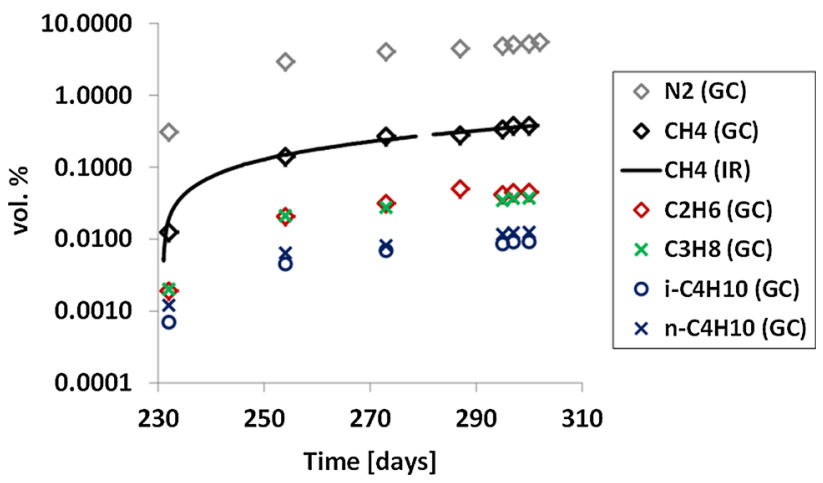

Fig. $4 \mathrm{~N}_{2}, \mathrm{CH}_{4}, \mathrm{C}_{2} \mathrm{H}_{6}, \mathrm{C}_{3} \mathrm{H}_{8}, \mathrm{i}-\mathrm{C}_{4} \mathrm{H}_{10}$, and $\mathrm{n}-\mathrm{C}_{4} \mathrm{H}_{10}$ content measured in the gas circulating in BPC-C1 borehole from the second argon purge onwards; logarithm scale; $G C$ gas chromatography; IR infrared spectrometry; analytical uncertainty is included within the symbol size

In borehole $\mathrm{BPC}-\mathrm{C} 1$, the $\mathrm{CO}_{2}$ concentration in the gas was lower by $0.5 \log$ unit than those at equilibrium with the pore-water calculated from the measurements of $\mathrm{pH}$, alkalinity, and total inorganic carbon and this discrepancy was not understood (Vinsot et al. 2008). In borehole BHT1 , the $\mathrm{CO}_{2}$ concentrations in the gas are very variable, unexpectedly low and far lower than those at equilibrium with the pore-water calculated from the measurements of $\mathrm{pH}$, alkalinity, and total inorganic carbon (Vinsot et al. 2014). The measurements of the gases have been checked and are not an issue. The current hypothesis for explaining the large deviations is that one of the items of equipment in the HT experiment (borehole BHT-1) and not in the PC-C experiment (borehole BPC-C1) might contain an adsorbing material acting as a $\mathrm{CO}_{2}$ trap. The equipment in question is currently thought to be the ceramic screen. Indeed, large pieces of this type of screen $\left(\approx 3 \mathrm{dm}^{3}\right)$ are present in BHT1 , while pieces only measuring a few $\mathrm{cm}^{3}$ were used in BPC-C1 to protect the line ends at the place where they exit the central tubing. This hypothesis is supported by similar observations in Andra's Meuse/Haute-Marne Underground Research Laboratory at Bure. In an experiment based on the same experimental layout, with the ceramic screens being replaced by PTFE (Lundy et al. 2013), the measured $\mathrm{CO}_{2}$ content in the gas phase was less than $0.5 \log$ unit lower than the $\mathrm{CO}_{2}$ partial pressure that was deduced from speciation calculations based on the water chemical analysis results. Laboratory tests and numerical modelling calculations are underway to assess the validity of this hypothesis.

\subsection{Natural gas content in seepage water}

Chemical compositions of dissolved gases were also measured on ten BPC-C1 water samples after the borehole 


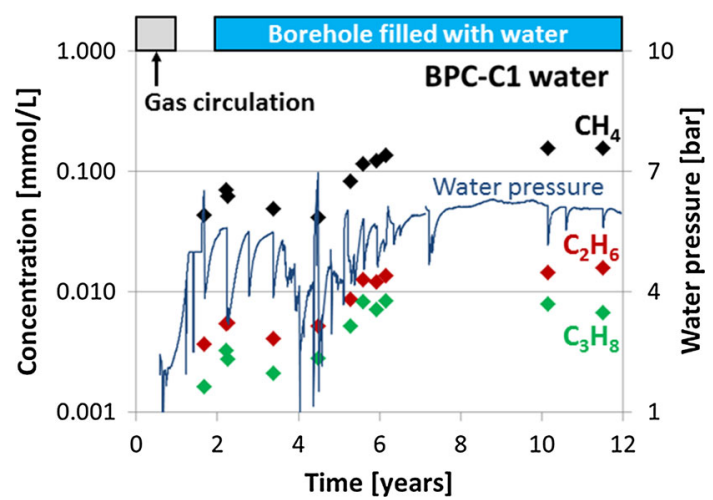

Fig. 5 Dissolved $\mathrm{CH}_{4}, \mathrm{C}_{2} \mathrm{H}_{6}$, and $\mathrm{C}_{3} \mathrm{H}_{8}$ concentrations measured in BPC-C1 seepage water; logarithm scale; analytical uncertainty is included within the symbol size; water pressure of the test interval measured in the drift at a vertical distance of 9.6 and $12.9 \mathrm{~m}$ from the bottom and from the top of the test interval, respectively; the water pressure into the test interval is 1.0 to 1.3 bar lower than the measured one

interval had been filled with water (Fig. 5; Electronic Appendix-Table 3). In the test interval, the water pressure varied over a range of several bar until the 7th year of the experiment. Then, it stabilized at a value larger than 5 bar. If this value was lower than the total pressure of the gases dissolved in the water, than gas bubbles should form and the dissolved gases should escape the water. If the opposite was true, the dissolved gases should remain in the water. In that case, measured values of dissolved gas concentrations should tend towards those that are representative of pristine pore-water. After 10 years of water composition monitoring, the measured methane concentration was $0.16 \mathrm{mmol} /$ $\mathrm{L}$, the measured ethane concentration was between 0.015 and $0.016 \mathrm{mmol} / \mathrm{L}$, and the measured propane concentration was between 0.007 and $0.008 \mathrm{mmol} / \mathrm{L}$. If they were stable, these values could be representative of the alkane concentrations in undisturbed pore-water. However, as they were still increasing, these values indicate the minimum concentrations of these three alkanes in Opalinus Clay pore-water at this location.

\subsection{Natural gas isotopes}

The isotopic composition of alkanes, up to $\mathrm{C} 3$, was measured in the gas and water samples. In both boreholes BPC$\mathrm{C} 1$ and BHT-1, the isotope contents of methane are scattered while those of heavier gases evolve more smoothly (Fig. 6; Electronic Appendix-Tables 1 to 3). The largest methane $\delta^{13} \mathrm{C}$ variations are observed when gas was added to or removed from the test interval. These operations induced gas fractionation between the lighter and the heavier gases. For all the alkanes, the $\delta^{13} \mathrm{C}$ values tend to decrease after a flushing of the test interval and to stabilize afterwards. Rayleigh fractionation could explain this

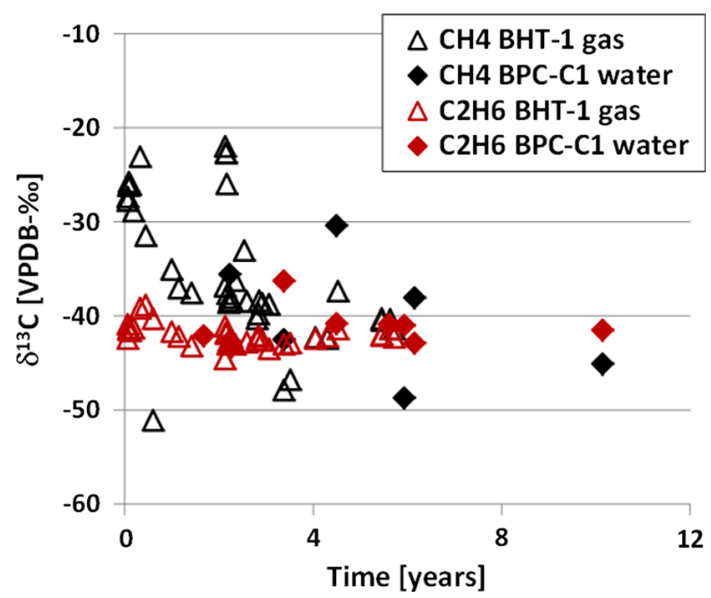

Fig. $6 \delta^{13} \mathrm{C}$ of $\mathrm{CH}_{4}$ and $\mathrm{C}_{2} \mathrm{H}_{6}$ measured in the gas circulating in BHT-1 and in BPC-C1 seepage water; analytical uncertainty is included within the symbol size

observation. The stabilized values are between -30 and $-45 \%$ VPDB for all alkanes in both boreholes.

\subsection{Injected gases}

After replacing the gas from the test interval with the mixture of gases containing $5 \mathrm{vol} \% \mathrm{H}_{2}, 5 \mathrm{vol} \% \mathrm{He}$, and $5 \mathrm{vol} \% \mathrm{Ne}$ in argon, all the injected gas concentrations decreased, $\mathrm{H}_{2}$ much faster than $\mathrm{He}$ and $\mathrm{Ne}$ (Vinsot et al. 2014; Fig. 7). The evolution of Ne concentration could be reproduced over the first year with a diffusion model, considering dissolution and diffusion in pore-water. The difference observed between the evolution of the He concentration and the evolution of the $\mathrm{Ne}$ concentration was interpreted as being due to a leak of $\mathrm{He}$ because $\mathrm{He}$ has a smaller atomic size than $\mathrm{Ne}$. In contrast, even with the possibility of a hydrogen leak, its concentration evolution was much faster than the leak rate.

\section{Modelling}

\subsection{Model description}

The model which had been constructed with PHREEQC-3 (Parkhurst and Appelo 2013) to describe the transport of the gas injected in the borehole to the surrounding rock (Vinsot et al. 2014) has also been used to simulate the transport of natural gases in the opposite direction in BHT1. The model calculates diffusional transport of the gases through the Opalinus Clay by explicit finite differences in a radial one-dimension configuration. Each dissolved gas is supposed to access the entire water-filled porosity but it is given its own diffusion coefficient in pure water (Appelo and Wersin 2007; Appelo et al. 2010). The effective 
Fig. 7 Changes in the $\mathrm{He}$ and $\mathrm{Ne}$ contents and in the gas pressure measured in the gas circulating in BHT-1 and calculated with PHREEQC; changes in the $\mathrm{H}_{2}$ content measured in the gas circulating in BHT- 1 over the time period of $\mathrm{H}_{2}$ injection
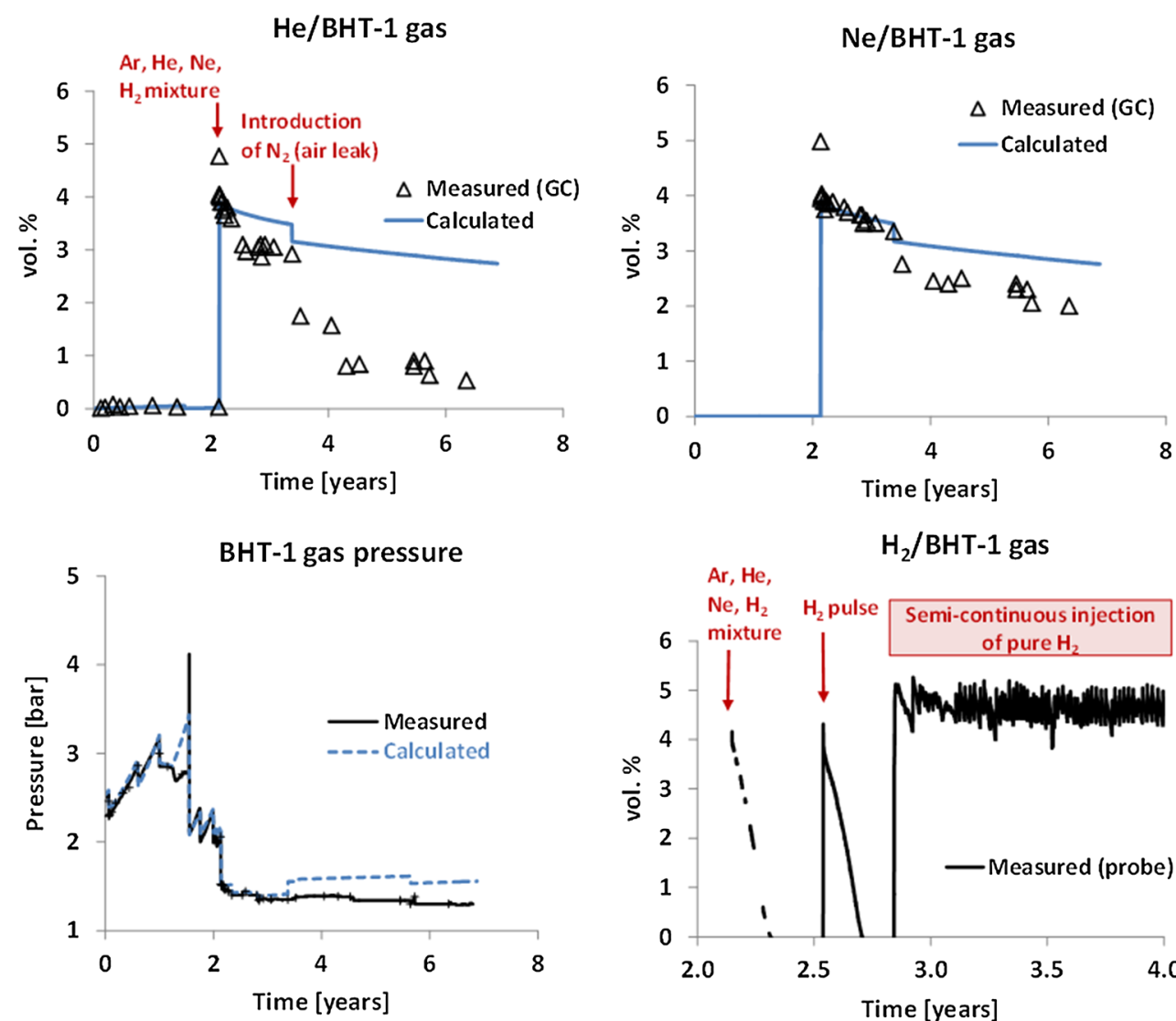

diffusion coefficient $D_{e}$ of each dissolved gas is related to its diffusion coefficient $D_{w}$ in pure water by $D_{e}=\varepsilon D_{w} / G$ with $\varepsilon$ the porosity and $G$ the geometric factor (see for example Van Loon and Mibus 2015). The porosity value is 0.16 . A G-value of $7.7 \pm 0.2$ parallel to bedding was obtained in situ for HTO in the same Opalinus Clay shaly facies at Mont Terri (Appelo and Wersin 2007). This value was used here in the model for all the dissolved gases (neutral species). The solubility values and diffusion coefficients used for the different dissolved gases are presented in Table 1.

Diffusion of gases over the water-gas interface is modelled with the two-film model of Liss and Slater (1974). This model allows obtaining the flux over a general interface by finding the concentration and the pressure at the boundary of water/gas (Appelo and Postma 2005). The gas and water concentrations are considered to be in equilibrium at the gas-water interface. The water-film thickness is assumed to be $0.25 \mathrm{~mm}$ (in agreement with calculations for other systems (Appelo and Postma 2005)). However, this value has little influence on the calculations, because the solute concentrations in the cell that borders the borehole are close to equilibrium with the gas concentrations (at the time and space discretization of the model). The wall surface area has been multiplied by a rugosity factor $R=10$ to take into account the surfaces created by the drilling in the damaged rock surrounding the borehole. This hypothesis has been previously applied for a very similar experiment performed in Andra's Meuse/ Haute-Marne Underground Research Laboratory (Trémosa et al. 2015). The rugosity factor modifies the gas fluxes that are exchanged with pore-water in the first cell of the model. It influences significantly the results when the conditions change rapidly in the gas, i.e. at the beginning of the coring phase or when the interval is flushed with a new gas mixture. Otherwise it does not change significantly the gas content evolution because this one is mainly controlled by the diffusion in the following cells. The sensitivity of the results to the value of the rugosity factor has been looked at. Increasing the value above 10 does not impact the results anymore. The advective part of the transport is not taken into account in the model as previous calculations showed that its impact on the gas content evolution was very small compared to diffusive transport. The geometric characteristics of the model used to describe the BHT-1 borehole are presented in Table 2 .

It has been verified that the model radial length was sufficiently large: the maximum distance of influence of the borehole on the dissolved gas contents in the rock porewater after 7 years is less than $2 \mathrm{~m}$ from the borehole 
Table 1 Solubilities $\left(-\log K_{H}\right.$, $K_{H}$ being the Henry constant) and diffusion coefficients for the gases in the model

\begin{tabular}{lcllc}
\hline $\mathrm{Gas}$ & $-\log K_{H}$ & $-\Delta \mathrm{H}_{\mathrm{r}}(\mathrm{kJ} / \mathrm{mol})$ & $D_{w}\left(10^{-9} \mathrm{~m}^{2} / \mathrm{s}\right)$ & $D_{e}\left(10^{-11} \mathrm{~m}^{2} / \mathrm{s}\right)$ \\
\hline $\mathrm{H}_{2} \mathrm{O}$ & -1.506 & -44.03 & 2.24 & 3.54 \\
$\mathrm{H}_{2}$ & 3.10 & (Polynomial) & 5.13 & 8.12 \\
$\mathrm{He}$ & 3.41 & (Polynomial) & 7.29 & 11.53 \\
$\mathrm{~N}_{2}$ & 3.19 & (Polynomial) & 1.96 & 3.10 \\
$\mathrm{Ne}$ & 3.35 & (Polynomial) & 4.04 & 6.39 \\
$\mathrm{Ar}$ & 2.86 & (Polynomial) & 2.45 & 3.88 \\
$\mathrm{CO}_{2}$ & 1.468 & (Polynomial) & 1.92 & 3.04 \\
$\mathrm{CH}_{4}$ & 2.85 & (Polynomial) & 1.85 & 2.93 \\
$\mathrm{C}_{2} \mathrm{H}_{6}$ & 2.69 & -19.5 & 1.53 & 2.42 \\
$\mathrm{C}_{3} \mathrm{H}_{8}$ & 2.85 & -22.2 & 1.29 & 2.04 \\
\hline
\end{tabular}

The solubilities (Scharlin et al. 1998) and diffusion coefficients in pure water $\left(\mathrm{D}_{\mathrm{w}}\right)$ are for $25^{\circ} \mathrm{C}$; value for HTO in water comes from Mills and Harris (1976); values for the gases $\mathrm{N}_{2}, \mathrm{Ar}, \mathrm{CH}_{4}$ and $\mathrm{CO}_{2}$ were taken from Table 4.4 in Boudreau (1997) and stem from Jähne et al. (1987) and Ohsumi and Horibe (1984). Values for the gases $\mathrm{C}_{2} \mathrm{H}_{6}$ and $\mathrm{C}_{3} \mathrm{H}_{8}$ come from Hayduk and Laudie (1974) and (Table 4.3 in Boudreau 1997), but multiplied by 1.1 to be commensurate with the higher diffusion coefficient for $\mathrm{CH}_{4}$ given by Jähne et al. (1987) compared with Hayduk and Laudie (1974); in the model, solubilities are corrected to $15.6{ }^{\circ} \mathrm{C}$ using Van't Hoff's equation with the dissolution reaction enthalpy $(\Delta H r)$ or with a polynomial; effective diffusion coefficients $\left(\mathrm{D}_{\mathrm{e}}\right)$ are corrected by accounting for the viscosity change of water with temperature at $15.6^{\circ} \mathrm{C}$

Table 2 Geometric characteristics of the PHREEQC model used for the BHT-1 experiment

\begin{tabular}{llllll}
\hline Initial gas volume & Interval length & Borehole radius & Radial length & Cell number & Cell size \\
\hline $9.5 \mathrm{~L}$ & $5 \mathrm{~m}$ & $38 \mathrm{~mm}$ & $4.9 \mathrm{~m}$ & 45 & $20-480 \mathrm{~mm}$ \\
\hline
\end{tabular}

centre; this distance is less than half the model radial length.

The total pressure in the test interval is calculated from the gas masses by using the ideal gas law. It is assumed that the gas mixture in the borehole remains homogeneous while the gases diffuse in-and-out of Opalinus Clay. The effect of the variation in water level is taken into account to evaluate the volume available for the gases and the area of the rock in contact with the circulating gas. The operations or events that occasionally modify either the total volume available for the gases or the total mass of gas are accounted for in the model (Electronic Appendix-Table 4). Operations of interest can be: (1) extracting water; (2) adding empty parts to the gas circuit, such as sampling cylinders containing 20 mbar argon, in which the circulating gas expands; (3) involuntary gas introduction or outflow.

\subsection{Modelling results}

\subsubsection{BHT-1 experiment}

Alkane concentrations in Opalinus Clay pore-water are the unknowns in the model. Furthermore, alkanes may be adsorbed onto rock solids. As a consequence, both the concentrations and the retention properties of each alkane have to be estimated. For each alkane, a linear retention coefficient $\mathrm{K}_{\mathrm{d}}^{\prime}$ was used in the model, such that the adsorbed alkane concentration $\mathrm{C}_{\mathrm{ads}}=\mathrm{K}_{\mathrm{d}}^{\prime} \times \mathrm{C}_{0}$; $\mathrm{C}_{0}$ corresponds to the dissolved alkane concentration; $\mathrm{K}_{\mathrm{d}}^{\prime}$ is dimensionless. The total content of the alkane under consideration is $\mathrm{C}_{\mathrm{t}}=\mathrm{C}_{0}+\mathrm{C}_{\mathrm{ads}}=\mathrm{C}_{0}\left(1+\mathrm{K}_{\mathrm{d}}^{\prime}\right)$. By using the bulk dry density value (mass of dry rock over volume of saturated rock, $\rho_{\mathrm{d}}=2.3 \mathrm{~g} / \mathrm{cm}^{3}$ ) of Opalinus Clay deduced from both bulk wet density and porosity values (Mazurek et al. 2008), one can calculate $K_{d}(L / k g)=K_{d}^{\prime} \times \varepsilon / \rho_{d}$ for each alkane. The values obtained for $\mathrm{C}_{0}$ and $\mathrm{K}_{\mathrm{d}}$ are presented in Table 3. Deduced partial pressures at equilibrium with Opalinus Clay pore-water and total concentration $\left(\mathrm{C}_{\mathrm{t}}\right)$ values are also presented in Table 3. Figures 7 and 8 show the comparison between observed and calculated contents for $\mathrm{He}, \mathrm{Ne}, \mathrm{N}_{2}$, methane, ethane, and propane, and the comparison between observed and calculated pressure. Hydrogen and $\mathrm{CO}_{2}$ contents evolve independently from the other dissolved gases (Vinsot et al. 2008, 2014; Cailteau et al. 2011a); hydrogen evolution involves consumption processes, whereas $\mathrm{CO}_{2}$ content is controlled by reactions with rock minerals and the ceramic screen in the case of 
Table 3 Concentrations, retention coefficients and partial pressures of $\mathrm{N}_{2}, \mathrm{CH}_{4}, \mathrm{C}_{2} \mathrm{H}_{6}$ and $\mathrm{C}_{3} \mathrm{H}_{8}$ in the rock surrounding the borehole BHT-1

\begin{tabular}{lllcc}
\hline Parameter & $\mathrm{N}_{2}$ & $\mathrm{CH}_{4}$ & $\mathrm{C}_{2} \mathrm{H}_{6}$ & $\mathrm{C}_{3} \mathrm{H}_{8}$ \\
\hline $\mathrm{K}_{\mathrm{d}}^{\prime}(-)$ & 0 & 0.25 & 3.98 & 12.59 \\
$\mathrm{~K}_{\mathrm{d}}(\mathrm{L} / \mathrm{kg})$ & 0 & 0.02 & 0.28 & 0.88 \\
$\mathrm{~K}_{\mathrm{d}}^{\mathrm{OM}}(\mathrm{L} / \mathrm{kg}$ organic C) & 0 & 2.18 & 34.62 & 109.47 \\
$\mathrm{C}_{0}(\mathrm{mmol} / \mathrm{L})$ & 2.2 & 0.30 & 0.023 & 0.0125 \\
$\mathrm{C}_{\mathrm{t}}(\mathrm{mmol} / \mathrm{L})$ & 2.2 & 0.375 & 0.115 & 0.170 \\
Partial pressure at equilibrium with $\mathrm{C}_{0}($ bar $)$ & 3.16 & 0.19 & 0.01 & 0.007 \\
\hline
\end{tabular}

$C_{O}$ concentration of the dissolved gas in pore-water, $C_{t}$ total concentration of the gas in the rock (except non-reversibly sorbed gas)
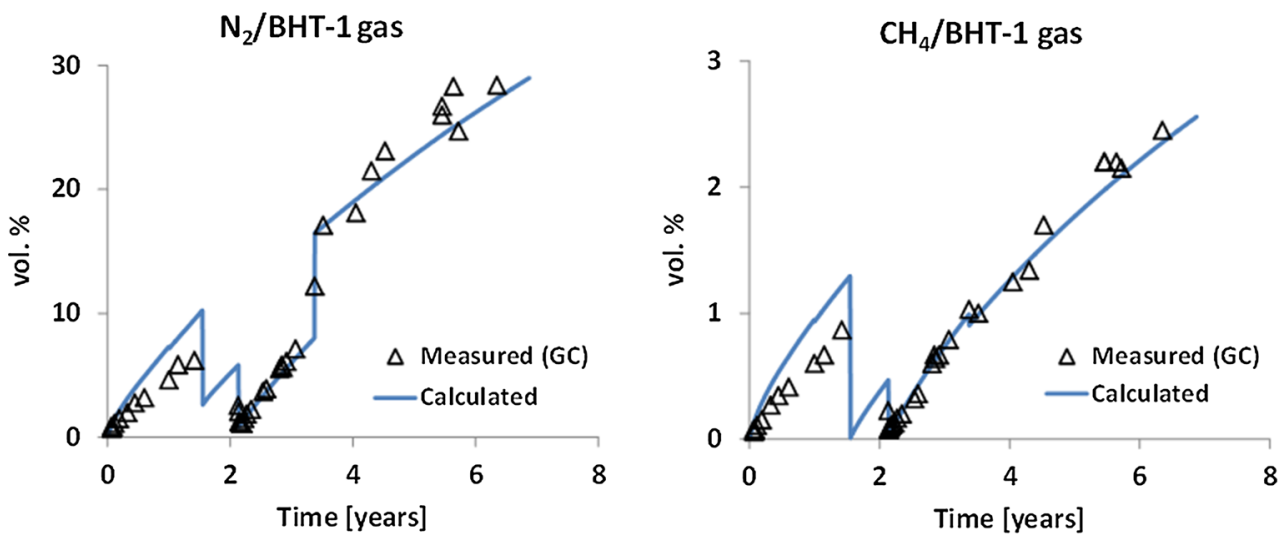

Fig. 8 Changes in the $N_{2}$ and alkane contents in the circulating gas measured in BHT-1 and calculated with PHREEQC

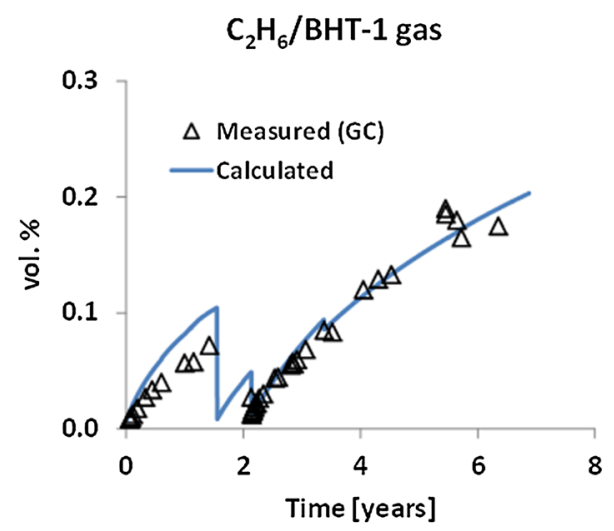

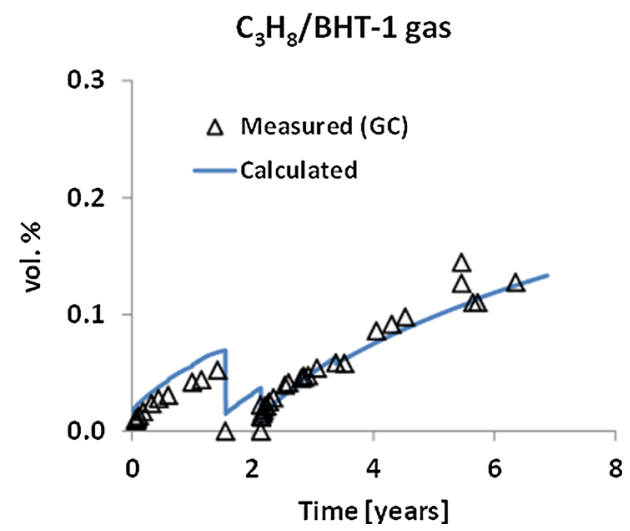

BHT-1. $\mathrm{H}_{2}$ and $\mathrm{CO}_{2}$ data are not commented here anymore as they do not impact non-reactive gas migration. However, the carbonate species and their equilibrium in solution are taken into account in the model.

On both days 220 (0.60 year) and 365 (1 year), respectively 100 and $160 \mathrm{~mL}$ water were extracted from the borehole BHT-1 by opening a water line valve. An unknown mass of gas escaped from the circuit at the end of the water extraction. In the model, the escaped masses of gases have been estimated (Electronic Appendix-Table 4) by adjusting the total pressure at these dates and assuming that all the gases escaped at the same rate, in proportion of their content in the borehole. From day 452 (1.24 year), a failure of the pressure controller prevented the water to be extracted from the borehole. As a consequence, the water level increased in the borehole interval, inducing a diminution of the volume available for the gases. In spite of this volume decrease, the measured gas pressure decreased, showing that gas was leaking out of the borehole. In the model, the water level increase is simulated however the leak is not giving a discrepancy between the measured and the calculated pressure (Fig. 7). An excess of $\mathrm{N}_{2}$ and alkanes is also calculated by the model with respect to the measurements during this time period (Fig. 8); the discrepancy may be mainly explained by the leak.

On day 1232 ( 3.4 years), the air introduction observed is modelled by adding $\mathrm{N}_{2}$ in the borehole. The mass of added $\mathrm{N}_{2}$ was adjusted to fit the measured $\mathrm{N}_{2}$ content (Electronic 
Appendix-Table 4). The introduction of air oxygen has not been taken into account, supposing that oxygen was consumed by reaction with components of the rock such as pyrite because it has been previously observed that this reaction is very fast. In spite of these modelling choices, the calculated pressure is larger than the observed one (Fig. 7). This result and also the evolution of Ne content that decreased faster than expected by the model after the air introduction, suggest that gases have escaped out of the circuit when air entered. As a consequence, the alkane concentrations in pore-water used in these simulations may be considered as minimum values.

Over the 4-year time period that began at the moment of the $\mathrm{H}_{2}-\mathrm{He}-\mathrm{Ne}-\mathrm{Ar}$ mixture injection, the calculated contents of $\mathrm{N}_{2}$ and alkanes and the calculated pressure in the borehole are in relative accordance with the measured ones (Figs. 7, 8). As already mentioned, the calculated $\mathrm{Ne}$ content is also in accordance with the measured one up until the air introduction event that occurred at day 1232 (3.4 years). On the other hand, the calculated He content agrees with the measured one only over the first 50 days (Fig. 7). However, from November 2011 until September 2012, the measured He content value was more or less stable, oscillating in the range of $3 \pm 0.1 \mathrm{vol} \%$. A possible explanation for this observation is that He escaped out of the gas circuit into the $500 \mathrm{~mL}$ hydrogen filled syringe. Subsequently, when the syringe injected hydrogen, it released back its He content at the same time. From the syringe, He could have also diffused into the 3 L-volume hydrogen reservoir. In that case, He recovery in the circulating gas could take several years and it could become undetectable.

The partial pressure of the dissolved $\mathrm{N}_{2}$ and $\mathrm{C} 1$ to $\mathrm{C} 3$ alkane estimated with the model is 3.4 bar at $16{ }^{\circ} \mathrm{C}$. This pressure corresponds to the pressure of these gases in a virtual gaseous phase which is in equilibrium with water. Based on this result, while taking into account the other dissolved gases present in the pore-water (i.e. $\mathrm{CO}_{2}$, heavier alkanes), the value of the total pressure of dissolved gases in Opalinus Clay pore-water, also named the "bubble point", is larger than 3.4 but it should not reach 4 bar.

\subsubsection{BPC-Cl experiment}

The model developed for the BHT-1 experiment was applied without any change regarding the parameters of interest (i.e. concentrations in Opalinus Clay pore-water, retention coefficients, diffusion coefficients of the dissolved gases) to calculate the gas content evolution in borehole BPC-C1. The events that affected this experiment are listed in Electronic Appendix-Table 5. For these calculations, the single hypothesis concerned the initial volume of the test interval and the precise volume of the tank. Assuming that the former was the theoretical one and that the tank volume value was either $0 \mathrm{~L}$ or $5.4 \mathrm{~L}$ (maximum value), we obtained the calculated curves presented in Fig. 9. The general agreement between measured and calculated data regarding alkane ( $\mathrm{C} 1$ to $\mathrm{C} 3$ ) contents suggests that alkane contents in Opalinus Clay pore-water could have the same range of values at the BPC-C1 location than at the BHT-1 location. Measured $\mathrm{N}_{2}$ content after the second argon purge (from day 231 onwards), was larger than the calculated one. At the beginning of this sequence, between the first two analytical results, the $\mathrm{N}_{2}$ content increased at an apparent rate close to $0.1 \%$ per day. However, the $\mathrm{N}_{2}$ content increase rate was only $0.05 \%$ per day between the second and the following analytical results. Moreover, the $\mathrm{CH}_{4}$ and the $\mathrm{N}_{2}$ contents are linearly correlated from the second analytical result onwards, whilst the first result is out of this relationship. These observations suggest that air $\mathrm{N}_{2}$ could have entered the gas circuit between the first two sampling operations.

\section{Discussion}

\subsection{Natural gas content and retention properties in Opalinus Clay at Mont Terri}

\subsubsection{Model sensitivity analysis}

Estimated values of $\mathrm{N}_{2}$ and $\mathrm{C} 1$ to $\mathrm{C} 3$ alkane concentration in Opalinus Clay pore-water at Mont Terri have been obtained thanks to in situ gas circulation experiments and by modelling diffusion and degassing of these gases with the code PHREEQC-3. The sensitivity of the results to the modelling parameters used (effective diffusion coefficient and volume values) has been checked. The effective diffusion coefficient $\left(\mathrm{D}_{\mathrm{e}}\right)$ used in the calculations was based on a porosity $(\varepsilon)$ value of $16 \%$ and a geometric factor $G$ value of $7.7\left(\varepsilon^{-1.11}\right)$. With this $\mathrm{D}_{\mathrm{e}}$ value, the $\mathrm{He}$ and $\mathrm{Ne}$ evolutions calculated reproduced satisfactorily the measured ones during the early 50 days for He and during more than one year for Ne. However $G$ values could depend on the gas molecule size in clay rich rocks (Jacops et al. 2013). Smaller $D_{e}$ values than the reference value would have prevented an acceptable fit for these gases, even during the early time period. On the other hand, porosity values close to $18 \%$ have been measured on BHT-1 core samples. $D_{e}$ values up to $22 \%$ larger than the reference value have been taken into account in the model. The maximum $\mathrm{D}_{\mathrm{e}}$ value considered corresponds to a $\mathrm{G}$ factor of $6.2\left(\varepsilon^{-1}\right)$. This increase of the diffusion coefficient does not significantly modify the calculated gas content evolution. The influence of the initial interval volume value within its uncertainty 
Fig. 9 Changes in the $\mathrm{N}_{2}$ and alkane contents measured in the gas circulating in BPC-C1 and calculated with PHREEQC
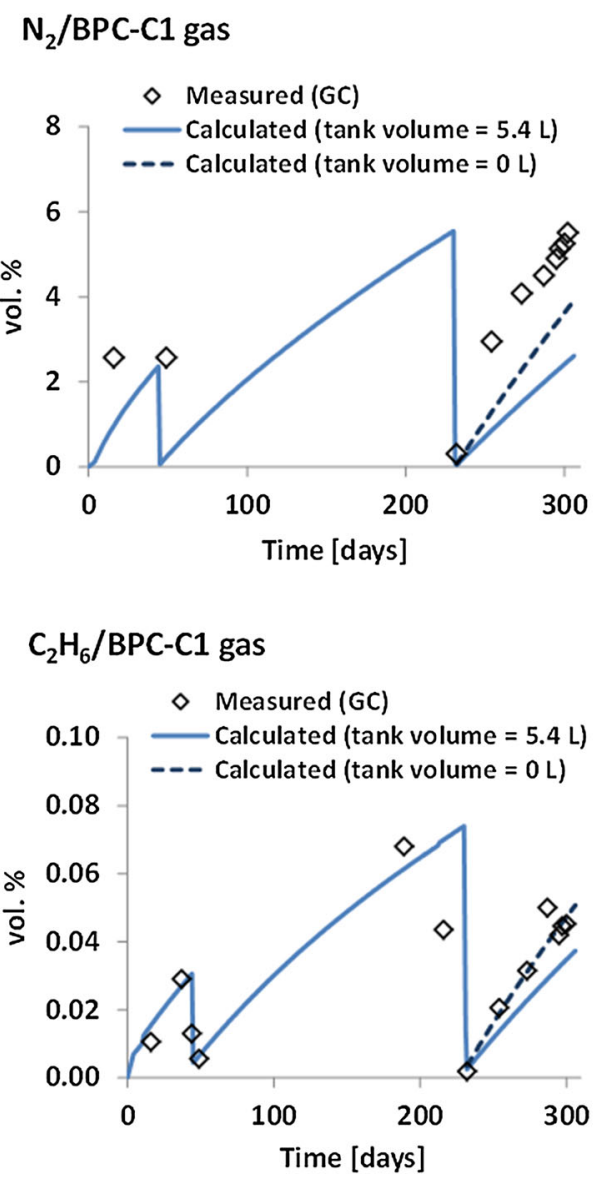

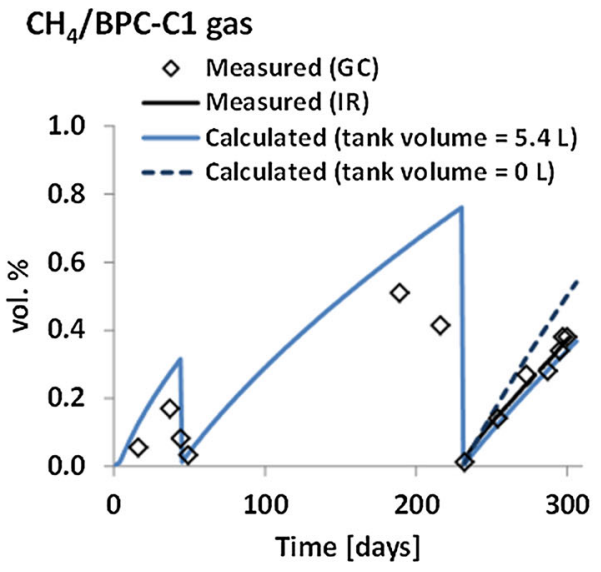

$\mathrm{C}_{3} \mathrm{H}_{8}$ /BPC-C1 gas

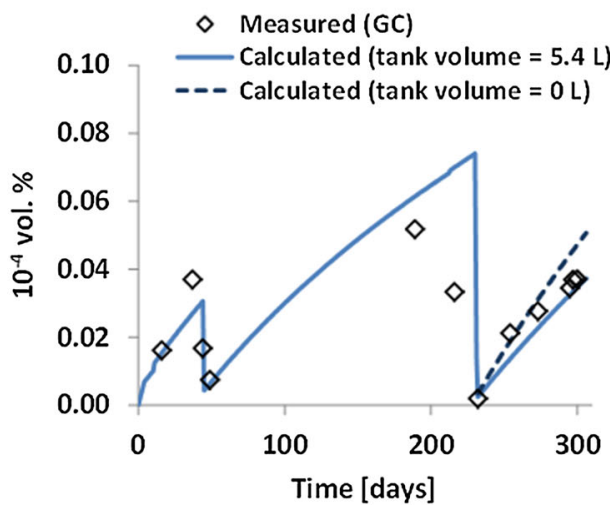

range on the gas content evolution is also minor. On the contrary, reducing the discrepancy between the measured and the calculated gas content values over the first 1.5 years of the BHT-1 experiment leads to a significant change in the natural gas contents of about $-25 \%$. This adjustment also leads to calculated values lower than the measured ones during the latest phase of the experiment (over the last 5 years). This difference in the $\mathrm{N}_{2}$ and alkane content values was assigned as being the uncertainty affecting them.

\subsubsection{Comparison with measurements on core samples}

Alkane total concentrations in Opalinus Clay rock have been measured in several Mont Terri cores, including a core from the borehole BHT-1 (Lerouge et al. 2015). Results are given in units of volume per mass of pore-water and may be compared to the $C_{t}$ values $(\mathrm{mmol} / \mathrm{L})$ obtained in the current study (Table 3). Regarding methane total concentration, the agreement is very good between the value obtained on the BHT-1 core $(0.009 \pm 0.0005 \mathrm{ccSTP} / \mathrm{g}$ pore-water $\approx 0.37 \pm$ $0.02 \mathrm{mmol} / \mathrm{L}$ ) and the value deduced from the gas circulation experiment $(0.375 \pm 0.10 \mathrm{mmol} / \mathrm{L})$. Regarding ethane and propane, the values obtained by modelling the borehole experiment $\quad(0.115 \pm 0.03 \mathrm{mmol} / \mathrm{L}$ for ethane and $0.170 \pm 0.05 \mathrm{mmol} / \mathrm{L}$ for propane) are only $56 \%$ and $33 \%$ by mass respectively of the values obtained from the analysis of the core gases $(0.005 \pm 0.0005 \mathrm{ccSTP} / \mathrm{g}$ pore-water $\approx 0.21 \pm 0.02 \mathrm{mmol} / \mathrm{L}$ for ethane and $0.0125 \pm 0.0005$ $\mathrm{ccSTP} / \mathrm{g}$ pore-water $\approx 0.52 \pm 0.02 \mathrm{mmol} / \mathrm{L}$ for propane). These discrepancies are larger than the uncertainties attached to the borehole values. On the other hand, the borehole values represent both the dissolved part and the reversibly adsorbed part of the alkanes, whereas the values measured in the core should really represent the alkane total concentrations. The latest could include a fraction of the alkanes that is non-reversibly adsorbed on the rock. Further investigations are necessary to assess this hypothesis.

\subsubsection{Alkane measurement on BPC-Cl borehole water}

Alkane concentrations measured in the BPC-C1 water are lower than those estimated from gas measurement in BHT1 ; i.e. the $\mathrm{BPC}-\mathrm{C} 1$ values represent half to two thirds of the BHT-1 values. On the other hand, the comparison between the alkane concentrations measured in BPC-C1 gas and the alkane concentrations calculated in BPC-C1 based on the BHT-1 model showed that the alkane concentrations could 
have the same range of values at the BPC-C1 location than at the BHT-1 location. As a consequence, the total pressure of dissolved gases in pristine pore-water should be comprised between 3.4 and 4 bar at the BPC-C1 location. In the BPC-C1 test interval, the water pressure has exceeded this value for about 4 years. Alkane content in the BPC-C1 water samples could still be affected by the last sampling operations that induced a pressure decrease down below the pore-water bubble point. As a result, the alkane concentrations would not have reached the pore-water pristine values yet.

\subsubsection{Alkane retention properties in Opalinus Clay}

Within the Opalinus Clay solid phase, organic matter has probably the largest affinity for alkanes when compared to the inorganic solids. We calculated $\mathrm{K}_{\mathrm{d}}^{\mathrm{OM}}(\mathrm{L} / \mathrm{kg})$ as being the retention coefficient of a given alkane on Opalinus Clay solid organic matter, by dividing the $\mathrm{K}_{\mathrm{d}}$ value of this alkane by the organic carbon content of the rock (0.8 wt.\%; Mazurek et al. 2008). These $\mathrm{K}_{\mathrm{d}}^{\mathrm{OM}}$ values (Table 3) were then compared with octanol/water partition coefficients $\mathrm{K}_{\mathrm{ow}}$ (Fig. 10). Methane, ethane, and propane $\mathrm{K}_{\mathrm{ow}}$ values were calculated by using the linear relationship between $\mathrm{K}_{\mathrm{ow}}$ and the carbon number described for alkane up to C10 (Molyneux 2014). The linear relationship between $\log \mathrm{K}_{\mathrm{d}}^{\mathrm{OM}}$ and $\log \mathrm{K}_{\mathrm{ow}}$ for the first three alkanes reinforce the confidence in the data interpretation proposed.

\subsubsection{Summary of the results regarding $N_{2}$ and alkane contents}

The natural content of four gases in Opalinus Clay porewater was evaluated at the experiment location: $\mathrm{N}_{2}$ $2.2 \pm 0.5 \mathrm{mmol} / \mathrm{L}, \quad \mathrm{CH}_{4} \quad 0.30 \pm 0.075 \mathrm{mmol} / \mathrm{L}, \quad \mathrm{C}_{2} \mathrm{H}_{6}$

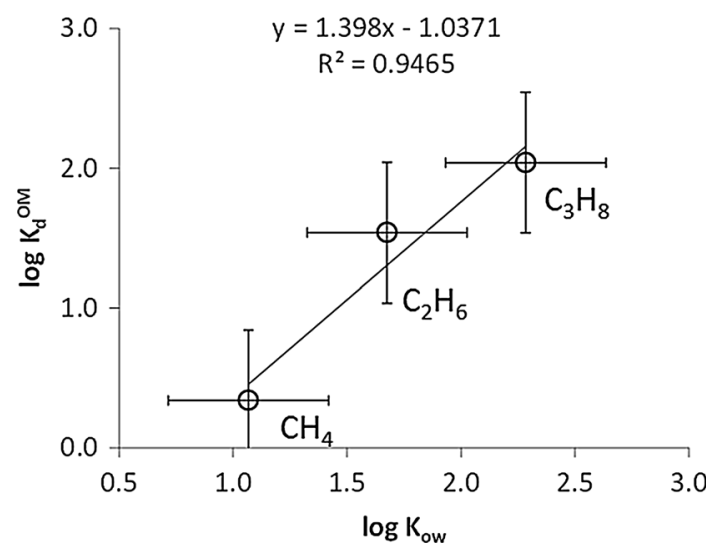

Fig. 10 Alkane $\mathrm{C} 1-\mathrm{C} 3$ retention coefficients on Opalinus Clay organic matter (L/kg organic carbon) deduced from the BHT-1 experiment versus octanol/water partition coefficients $\left(\mathrm{K}_{\mathrm{ow}}\right)$
$0.023 \pm 0.005 \mathrm{mmol} / \mathrm{L}, \quad \mathrm{C}_{3} \mathrm{H}_{8} \quad 0.012 \pm 0.003 \mathrm{mmol} / \mathrm{L}$. These results provide a minimum value of $3.4 \mathrm{bar}$ for the "bubble point" of Opalinus Clay pore-water at this location by using a thermodynamic equilibrium calculation and the gas solubility values presented in Table 1. Retention coefficients of alkanes on Opalinus Clay have been estimated. The values obtained for methane, ethane, and propane are linearly correlated on a log/log diagram with their octanol/water partition coefficient values, supporting the hypothesis that the alkanes are adsorbed on Opalinus Clay organic matter.

\subsection{Origin of Opalinus Clay $\mathrm{N}_{2}$ and alkanes}

In the BHT-1 circulating gas, amongst the alkanes up to C6 observed, methane represents between 67 and $87 \%$ by mass; ethane represents between 6 and $12 \%$ and propane represents between 4 and 12\%. These ratio values evolved over time as the result of distillation-type processes (Fig. 11). The ratio values deduced from the analyses performed on the last gas samples from BPC-C1 and from other borehole headspaces (BWS-A1, BWS-A2, and BWSA3) at Mont Terri (Pearson et al. 2003) are in the same range (Fig. 12). In the rock, the methane fraction of the alkanes obtained on a BHT-1 core sample (Lerouge et al. 2015) was $34 \%$. In the present study, the methane fraction of the alkanes calculated in the rock surrounding the BHT1 borehole is $56 \%$. However, a fraction of the alkanes nonreversibly adsorbed on the rock could be missing in the alkane inventory. As a consequence, the methane fraction of the alkanes is probably smaller than 50\% in Opalinus Clay at the BHT- 1 experiment location. The $\delta^{13} \mathrm{C}$ isotopic compositions of the $\mathrm{C} 2-\mathrm{C} 4$ alkanes are similar in all the boreholes and in the BHT-1 core (Fig. 13), although methane $\delta^{13} \mathrm{C}$ values are more scattered. These results are consistent with the hypothesis of a thermogenic origin of the alkanes already proposed by Pearson et al. (2003). As

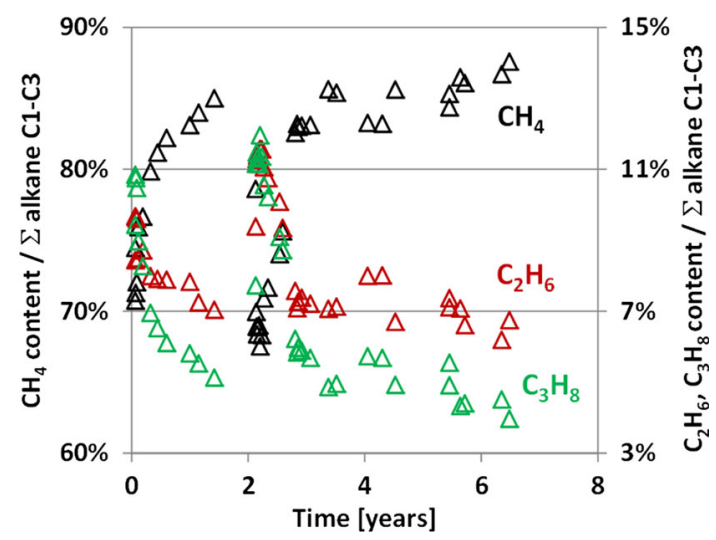

Fig. 11 Evolution of alkane $\mathrm{C} 1-\mathrm{C} 3$ relative proportion by mass observed in the BHT-1 circulating gas 


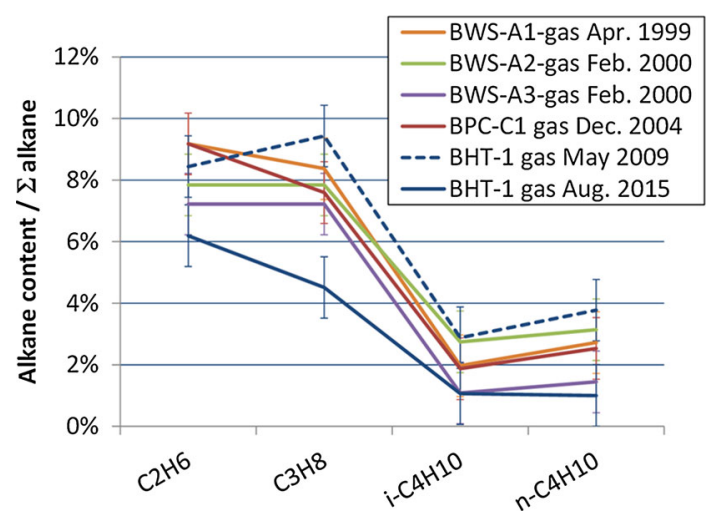

Fig. 12 Alkane C1-C4 relative content in gas sampled in several Mont Terri boreholes (data from Pearson et al. 2003 and this study)

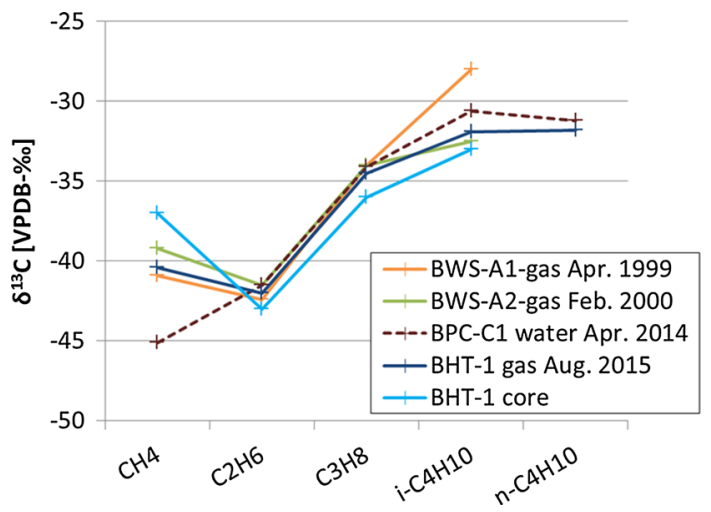

Fig. 13 Alkane C1-C4 carbon isotopic composition in gas sampled in several Mont Terri boreholes (data from Pearson et al. 2003 and this study) and extracted from a BHT-1 core sample (data from Lerouge et al. 2015); analytical uncertainty is included within the symbol size

complementary information, Opalinus Clay burial history indicates that it was exposed at temperature up to $85{ }^{\circ} \mathrm{C}$ (Mazurek et al. 2006) during several millions years. Moreover, the evaluation of a lower methane fraction in total alkanes than previously estimated from gas sampling tends to reinforce this hypothesis (Whiticar 1999). Furthermore, the chemical and carbon isotopic compositions of alkanes appear to be similar from one another location within Opalinus Clay at Mont Terri. This observation suggests that all the alkanes encountered in Opalinus Clay at Mont Terri arise from a common source, that they were produced at the same rate and that they have undergone similar migration chronicles. Regarding $\mathrm{N}_{2}$, it may originate from the alteration of organic and/or inorganic sedimentary matter during diagenesis (Krooss et al. 1995, 2005; Grishina et al. 1998). Both $\mathrm{N}_{2}$ and alkanes could have been produced either inside or outside the Opalinus Clay, for example in underlying formations that are rich in organic matter.

\subsection{Transport properties of dissolved gas in Opalinus Clay at Mont Terri}

The dissolved $\mathrm{N}_{2}$ and alkane concentration values in Opalinus Clay pore-water were estimated with a diffusion model calculation. The diffusion coefficients used in this calculation were taken from the literature. The geometric factor value for the dissolved gases was the one which had been determined for HTO parallel to bedding in the same environment. It made it possible to reproduce with the model the evolution of $\mathrm{Ne}$ concentration observed in the borehole BHT-1 over the first year up until an air introduction event. This result confirms that HTO diffusion parameters may be applied to a dissolved gas like neon in Opalinus Clay. Sensitivity of the results to the geometric factor value was studied and a variation within a realistic range did not significantly modify the estimated values of the $\mathrm{N}_{2}$ and alkane concentrations in Opalinus Clay porewater. The general consistency between the experimental and modelling results obtained in both gas circulation experiments gives a strong confidence that the processes taken into account in the model represent correctly the actual processes.

\section{Conclusion}

Two gas circulation experiments in Opalinus Clay at Mont Terri, that have been monitored for 12 and 7 years respectively, made it possible to evaluate the chemical and carbon isotopic compositions of the natural gases dissolved in the pore-water. The latest result of these experiments is that $\mathrm{N}_{2}$ is the most abundant dissolved gas $(2.2 \pm 0.5 \mathrm{mmol} / \mathrm{L})$ in Opalinus Clay pore-water at Mont Terri. Together with methane, ethane, propane, and $\mathrm{CO}_{2}$, dissolved $\mathrm{N}_{2}$ lead to a total gas pressure value at equilibrium with Opalinus Clay pristine pore-water at the location of the experiments larger than 3.4 bar. As a consequence, gas bubbles may form in the rock surrounding the galleries wherever the total water pressure is smaller than this value.

Retention properties of $\mathrm{C} 1$ to $\mathrm{C} 3$ alkanes in Opalinus Clay were deduced from the gas circulation experiments. Expressed as distribution numbers, they are $0.02 \mathrm{~L} / \mathrm{kg}$ for methane, 0.28 for ethane and 0.88 for propane. These values are linearly correlated with $\mathrm{K}_{\mathrm{ow}}$ values on a $\log / \log$ diagram, suggesting that the alkanes are adsorbed onto Opalinus Clay organic matter. Alkane proportions and their carbon isotopic compositions obtained are similar to previously published results and they are consistent with the hypothesis of a thermogenic origin. $\mathrm{N}_{2}$ is thought to arise from the same origin. Regarding dissolved gas diffusion in Opalinus Clay, the geometric factor that has been determined for HTO in the same environment was shown to 
apply to neon. As a consequence, it was used to simulate the diffusion of $\mathrm{N}_{2}$ and alkanes $\mathrm{C} 1$ to $\mathrm{C} 3$. The gas circulation experiments performed made it possible: (1) to test in situ our description of both the gas exchange processes at the interface between the saturated rock and a gas phase and the gas migration processes into a clay rich rock; (2) to evaluate the natural dissolved gas concentration and their retention properties in the host rock.

Acknowledgements We appreciate the fruitful discussions with Andreas Gautschi, Christophe Tournassat, Urs Mäder, Elie Valcke, Nick Waber, Paul Wersin, Hans-Eike Gäbler, Ana Maria Fernandez, Jennifer McKelvie, Dani Traber, and many other partners during the Mont Terri geochemical meetings. We gratefully thank Gesine Lorenz, Thomas Fierz, Thierry Theurillat, Patrick Delage, and Philippe Tabani for their involvement in the realization of the experiments, Karen Fournier for English advice and Jacques Delay, Sarah Dewonck, Christophe Nussbaum, and Paul Bossart for their continuous support of the project. We warmly acknowledge Thomas Gimmi and Martin Mazurek for their very accurate reading of the manuscript. PC-C and/or HT experiments benefited from financial support by Andra (France), Nagra (Switzerland), CEN-SCK (Belgium), BGR (Germany), and NWMO (Canada).

Open Access This article is distributed under the terms of the Creative Commons Attribution 4.0 International License (http://crea tivecommons.org/licenses/by/4.0/), which permits unrestricted use, distribution, and reproduction in any medium, provided you give appropriate credit to the original author(s) and the source, provide a link to the Creative Commons license, and indicate if changes were made.

\section{References}

Appelo, C. A. J., \& Postma, D. (2005). Geochemistry, groundwater and pollution (2nd ed.). Boca Raton: CRC Press.

Appelo, C. A. J., Van Loon, L. R., \& Wersin, P. (2010). Multicomponent diffusion of a suite of tracers ( $\mathrm{HTO}, \mathrm{Cl}, \mathrm{Br}, \mathrm{I}, \mathrm{Na}, \mathrm{Sr}, \mathrm{Cs}$ ) in a single sample of Opalinus Clay. Geochimica et Cosmochimica Acta, 74(4), 1201-1219.

Appelo, C. A. J., \& Wersin, P. (2007). Multicomponent diffusion modeling in clay systems with application to the diffusion of tritium, iodide, and sodium in Opalinus Clay. Environmental Science and Technology, 41(14), 5002-5007.

Bossart, P., Bernier, F., Birkholzer, J., Bruggeman, C., Connolly, P., Dewonck, S., Fukaya, M., Herfort, M., Jensen, M., Matray, J-M., Mayor, J. C., Moeri, A., Oyama, T., Schuster, K., Shigeta, N., Vietor, T., \& Wieczorek, K. (2017). Mont Terri rock laboratory, 20 years: Introduction, geology and overview of papers included in the Special Issue. Swiss Journal of Geosciences, 110. doi:10. 1007/s00015-016-0236-1 (this issue).

Boudreau, B. P. (1997). Diagenetic models and their implementation: modelling transport and reactions in aquatic sediments. Berlin: Springer.

Cailteau, C., de Donato, P., Pironon, J., Vinsot, A., Garnier, C., \& Barres, O. (2011a). In situ gas monitoring in clay rocks: Mathematical developments for $\mathrm{CO}_{2}$ and $\mathrm{CH}_{4}$ partial pressure determination under non-controlled pressure conditions using FT-IR spectrometry. Analytical Methods, 3(4), 888-895.

Cailteau, C., Pironon, J., de Donato, P., Vinsot, A., Fierz, T., Garnier, C., et al. (2011b). FT-IR metrology aspects for on-line monitoring of $\mathrm{CO}_{2}$ and $\mathrm{CH}_{4}$ in underground laboratory conditions. Analytical Methods, 3(4), 877-887.

Delay, J., Bossart, P., Ling, L. X., Blechschmidt, I., Ohlsson, M., Vinsot, A., et al. (2014). Three decades of underground research laboratories: What have we learned? Geological Society, London, Special Publications, 400(1), 7-32.

Gaucher, E. C., Tournassat, C., Pearson, F. J., Blanc, P., Crouzet, C., Lerouge, C., et al. (2009). A robust model for pore-water chemistry of clayrock. Geochimica et Cosmochimica Acta, 73(21), 6470-6487.

Grishina, S., Pironon, J., Mazurov, M., Sergey, G., Pustilnikov, A., Fon-Der-Flaas, G., et al. (1998). Organic inclusions in salt. Part 3. Oil and gas inclusions in Cambrian evaporite deposit from East Siberia. A contribution to the understanding of nitrogen generation in evaporites. Organic Geochemistry, 28(5), 297-310.

Hayduk, W., \& Laudie, H. (1974). Prediction of diffusion coefficients for nonelectrolytes in dilute aqueous solutions. AIChE Journal, 20(3), 611-615.

Jacops, E., Volckaert, G., Maes, N., Weetjens, E., \& Govaerts, J. (2013). Determination of gas diffusion coefficients in saturated porous media: $\mathrm{He}$ and $\mathrm{CH}_{4}$ diffusion in Boom Clay. Applied Clay Science, 83, 217-223.

Jähne, B., Heinz, G., \& Dietrich, W. (1987). Measurement of the diffusion coefficients of sparingly soluble gases in water. Journal of Geophysical Research: Oceans, 92(C10), 10767-10776.

Krooss, B. M., Friberg, L., Gensterblum, Y., Hollenstein, J., Prinz, D., \& Littke, R. (2005). Investigation of the pyrolytic liberation of molecular nitrogen from Palaeozoic sedimentary rocks. International Journal of Earth Sciences, 94(5), 1023-1038.

Krooss, B. M., Littke, R., Müller, B., Frielingsdorf, J., Schwochau, K., \& Idiz, E. F. (1995). Generation of nitrogen and methane from sedimentary organic matter: Implications on the dynamics of natural gas accumulations. Chemical Geology, 126(3), 291-318.

Lerouge, C., Blessing, M., Flehoc, C., Gaucher, E. C., Henry, B., Lassin, A., et al. (2015). Dissolved $\mathrm{CO}_{2}$ and alkane gas in clay formations. Procedia Earth and Planetary Science, 13, 88-91.

Liss, P. S., \& Slater, P. G. (1974). Flux of gases across the air-sea interface. Nature, 247(5438), 181-184.

Lundy, M., Garitte, B., Lettry, Y., \& Vinsot, A. (2013). Experimental design for in situ characterization of the Callovo-Oxfordian pore-water composition at $85{ }^{\circ} \mathrm{C}$. Procedia Earth and Planetary Science, 7, 533-536.

Lundy, M., \& Vinsot, A. (2010). Implementation of Raman and mass spectrometry for on line measurement of gas composition in boreholes. In Andra (Ed.), Clays in Natural and Engineered Barriers for Radioactive Waste Confinement, 4th International Meeting, Nantes, France, March 29-April 1st, 2010, Abstracts (pp. 535-536).

Mazurek, M., Alt-Epping, P., Bath, A., Gimmi, T., Niklaus Waber, H., Buschaert, S., et al. (2011). Natural tracer profiles across argillaceous formations. Applied Geochemistry, 26(7), $1035-1064$.

Mazurek, M., Gautschi, A., Marschall, P., Vigneron, G., Lebon, P., \& Delay, J. (2008). Transferability of geoscientific information from various sources (study sites, underground rock laboratories, natural analogues) to support safety cases for radioactive waste repositories in argillaceous formations. Physics and Chemistry of the Earth, Parts $A / B / C$, 33, S95-S105.

Mazurek, M., Hurford, A. J., \& Leu, W. (2006). Unravelling the multi-stage burial history of the Swiss Molasse Basin: Integration of apatite fission track, vitrinite reflectance and biomarker isomerisation analysis. Basin Research, 18(1), 27-50.

McCollom, T. M., Lollar, B. S., Lacrampe-Couloume, G., \& Seewald, J. S. (2010). The influence of carbon source on abiotic organic 
synthesis and carbon isotope fractionation under hydrothermal conditions. Geochimica et Cosmochimica Acta, 74(9), $2717-2740$.

Mills, R., \& Harris, K. R. (1976). The effect of isotopic substitution on diffusion in liquids. Chemical Society Reviews, 5, 215-231.

Molyneux, P. (2014). Octanol/water partition coefficients Kow: A critical examination of the value of the methylene group contribution to $\log$ Kow for homologous series of organic compounds. Fluid Phase Equilibria, 368, 120-141.

Nussbaum, C., Kloppenburg, A., Caër, T., \& Bossart, P. (2017). Tectonic evolution around the Mont Terri rock laboratory, northwestern Swiss Jura: constraints from kinematic forward modelling. Swiss Journal of Geosciences, 110. doi:10.1007/ s00015-016-0248-x (this issue).

Ohsumi, T., \& Horibe, Y. (1984). Diffusivity of He and Ar in deepsea sediments. Earth and Planetary Science Letters, 70(1), $61-68$.

Parkhurst, D. L., \& Appelo, C. A. J. (2013). Description of input and examples for PHREEQC version 3: A computer program for speciation, batch-reaction, one-dimensional transport, and inverse geochemical calculations. US geological survey techniques and methods, 6-A43.

Pearson, F. J., Arcos, D., Bath, A., Boisson, J. Y., Fernandez, A. M., Gäbler, H.-E., Gaucher, E., Gautschi, A., Griffault, L., Henàn, P. W., \& Wabe H. N. (2003). Mont Terri Project-Geochemistry of water in the Opalinus Clay Formation at the Mont Terri rock laboratory. Bern: OFEG Report, Geology Serie, No. 5. Federal Office of Topography (swisstopo), Wabern, Switzerland. http:// www.mont-terri.ch

Pearson, F. J., Tournassat, C., \& Gaucher, E. C. (2011). Biogeochemical processes in a clay formation in situ experiment: Part E-Equilibrium controls on chemistry of pore water from the Opalinus Clay, Mont Terri Underground Research Laboratory, Switzerland. Applied Geochemistry, 26(6), 990-1008.

Prinzhofer, A., Girard, J. P., Buschaert, S., Huiban, Y., \& Noirez, S. (2009). Chemical and isotopic characterization of hydrocarbon gas traces in porewater of very low permeability rocks: The example of the Callovo-Oxfordian argillites of the eastern part of the Paris Basin. Chemical Geology, 260(3), 269-277.

Prinzhofer, A., \& Pernaton, É. (1997). Isotopically light methane in natural gas: bacterial imprint or diffusive fractionation? Chemical Geology, 142(3), 193-200.

Rübel, A. P., Sonntag, C., Lippmann, J., Pearson, F. J., \& Gautschi, A. (2002). Solute transport in formations of very low permeability: Profiles of stable isotope and dissolved noble gas contents of pore water in the Opalinus Clay, Mont Terri, Switzerland. Geochimica et Cosmochimica Acta, 66(8), 1311-1321.

Scharlin, P., Battino, R., Silla, E., Tuii, I., \& Pascual-Ahuir, J. L. (1998). Solubility of gases in water: Correlation between solubility and the number of water molecules in the first solvation shell. Pure Applied Chemistry, 70(10), 1895-1904.
Sherwood Lollar, B., Lacrampe-Couloume, G., Voglesonger, K., Onstott, T. C., Pratt, L. M., \& Slater, G. F. (2008). Isotopic signatures of $\mathrm{CH}_{4}$ and higher hydrocarbon gases from Precambrian Shield sites: A model for abiogenic polymerization of hydrocarbons. Geochimica et Cosmochimica Acta, 72(19), $4778-4795$.

Stolper, D. A., Martini, A. M., Clog, M., Douglas, P. M., Shusta, S. S., Valentine, D. L., et al. (2015). Distinguishing and understanding thermogenic and biogenic sources of methane using multiply substituted isotopologues. Geochimica et Cosmochimica Acta, $161,219-247$.

Tabani, P., Hermand, G., Delay, J., \& Mangeot, A. (2010). Geoscientific Data Acquisition and management System (SAGD) of the Andra Meuse/Haute-Marne research center. In Andra (Ed.), Clays in Natural and Engineered Barriers for Radioactive Waste Confinement, 4th International Meeting, Nantes, France, March 29-April 1st, 2010, Abstracts (pp. 253-254).

Thury, M., \& Bossart, P. (1999). The Mont Terri rock laboratory, a new international research project in a Mesozoic shale formation, Switzerland. Engineering Geology, 52(3), 347-359.

Tournassat, C., Vinsot, A., Gaucher, E. C., \& Altmann, S. (2015). Chapter 3: Chemical conditions in clay-rocks. In C. Tournassat, C. I. Steefel, I. C. Bourg, \& F. Bergaya (Eds.), Developments in clay science (Vol. 6, pp. 71-100). Amsterdam: Elsevier.

Trémosa J., Hadi J., Claret F., Tournassat C., \& Vinsot A. (2015). Kinetic experiments in order to determine the rate of oxygen consumption by the Callovo-Oxfordian Argillaceous rock. In Clays in Natural and Engineered Barriers for Radioactive Waste Confinement, 6th International Meeting, Brussels, Belgium, March 23-26, 2015, Abstracts (pp. 116-117).

Van Loon, L. R., \& Mibus, J. (2015). A modified version of Archie's law to estimate effective diffusion coefficients of radionuclides in argillaceous rocks and its application in safety analysis studies. Applied Geochemistry, 59, 85-94.

Vinsot, A., Appelo, C. A. J., Cailteau, C., Wechner, S., Pironon, J., De Donato, P., et al. (2008). $\mathrm{CO}_{2}$ data on gas and pore water sampled in situ in the Opalinus Clay at the Mont Terri rock laboratory. Physics and Chemistry of the Earth, Parts $A / B / C, 33$, S54-S60.

Vinsot, A., Appelo, C. A. J., Lundy, M., Wechner, S., Lettry, Y., Lerouge, C., et al. (2014). In situ diffusion test of hydrogen gas in the Opalinus Clay. Geological Society, London, Special Publications, 400(1), 563-578.

Whiticar, M. J. (1999). Carbon and hydrogen isotope systematics of bacterial formation and oxidation of methane. Chemical Geology, 161(1), 291-314.

Zhang, T., \& Krooss, B. M. (2001). Experimental investigation on the carbon isotope fractionation of methane during gas migration by diffusion through sedimentary rocks at elevated temperature and pressure. Geochimica et Cosmochimica Acta, 65(16), 2723-2742. 